\title{
Residual Level, Profile and Potential Ecological Risk of Organochlorine Pesticides in Subsurface Sediments from Lakeshore Backfill Site and Lakebed of an Abandoned Oxidation Pond After Desilting for 15 Years
}

\author{
Ya-Fen Wang ( $\nabla$ wangyf@cug.edu.cn ) \\ Tao Liu \\ China University of Geosciences(Wuhan) \\ JinCan Tang \\ China University of Geosciences \\ ZhiWei Xiong \\ China University of Geosciences(Wuhan) \\ LiangChu Song \\ China University of Geosciences \\ Teng Ma \\ China University of Geosciences
}

China University of Geosciences (Wuhan) https://orcid.org/0000-0002-4336-0474

\section{Research Article}

Keywords: Organochlorine pesticides, distribution, dredged sediment, pollution source, ecological impact, microbial community structure

Posted Date: June 2nd, 2021

DOI: https://doi.org/10.21203/rs.3.rs-510071/v1

License: @ (i) This work is licensed under a Creative Commons Attribution 4.0 International License. Read Full License 


\section{Abstract}

The occurrence and distribution of 19 organochlorine pesticides (OCPS), together with microbial ester-linked fatty acid methyl ester (EL-FAME) profiles were investigated in sediments from an abandoned oxidation pond of Ya-Er lake, China, which had been heavily polluted by hexachlorocyclohexanes $(\mathrm{HCHs})$ and chlorobenzenes in 1980s. Subsurface sediment samples were taken from five sediment cores along the transect running from lakeshore to lakebed. The concentration of total OCPs ranged from 29.8 to $941.8 \mathrm{ng} \mathrm{g}^{-1} \mathrm{dw}$, with a mean value of $193.3 \mathrm{ng} \mathrm{g}^{-1} \mathrm{dw}$. Hexachlorobenzene (HCB), HCHs and dichlorodiphenyl-trichloroethanes (DDTs) were the three dominant OCP classes, accounting for $26.5 \%-97.4 \%$, $1.8 \%-51.5 \%$, and $0.4 \%-15.5 \%$ of the total, respectively. Hot spots of HCB, HCHs and DDTs were detected in 0.9-2.7 m deep layers of the lakeshore, where was one of the dredged sediment backfill sites for in-situ remediation of the oxidation pond in 2002-2004. High potential risks of HCHs and HCB were still indicated. Historical industrial input (27.2\%), recent agricultural input (14.7\%), and persistent residuals (14.3\%) were the three major identified sources of OCPs, using Absolute Principal Component Scores-Multiple Linear Regression (APCS-MLR). Redundancy analysis of microbial ELFAME profiles and nine dominant OCPs revealed that the spatial variation in microbial community structure was significantly corresponded with the OCP composition. This is the first study highlighted the concern on historical industrial inputs of OCPs in subsurface sediments of the lakeshore disposal zone. The findings could help to distinguish the artificial backfill sediments from natural polluted sediments for optimization of further desilting plans.

\section{Introduction}

Organochlorine pesticides (OCPs) are synthetic chlorinated compounds that contribute to agriculture production worldwide (Jayaraj et al. 2016). They can enter the aquatic environment through industrial and domestic discharges, agricultural runoff, and atmospheric deposition after long-distance transfer (Bhattacharya et al. 2003; Qu et al. 2019). Owing to their high hydrophobicity and resistance to degradation in the environment, OCPs tend to accumulate in sediments with long half-lives, and in aquatic organisms through food chain, posing adverse effects, i.e., hormone-like effects to biota and human (Tsai 2010; Lyall et al. 2017). Consequently, although the production and usage of OCPs have been strictly limited, OCP pollution in aquatic sediments is still of global concern (Helm et al. 2011; Wang et al. 2013; Dirbaba et al. 2018).

Most notably, extremely high levels of OCPs have been reported in sediments surrounding industrial units that synthesize these chemicals, such as Ya-Er lake area in Hubei, central China, Lake Ørsjøen, Southern Norway: McGrath Lake, USA (Brevik et al. 1996; Wu et al. 1997; Anderson et al. 2013). In most cases, sediment remediation projects have been carried out, and one of the most frequent remediation solutions adopted for those heavily polluted sediments is "dig and dump", involving disposal of the dredged sediments in a confined disposal facility or on low-lying areas (Clément et al. 2010; Gomes 2013; Liu et al. 2018). There were millions $\mathrm{m}^{3}$ of dredged sediments produced per project, which might result in severe secondary pollution and uncertain ecological threats to the surrounding environment and human health, if not properly treated. However, there were limited documentation on quantitative assessment of the ecological impairment of the residual pollutants coupled to chemical monitoring in the disposal fields (Zarull et al. 2002). The long-term fate and ecological impacts of OCP residues in dredged sediments deposited into aquatic ecosystem are therefore important topics of study.

Aquatic sediments serve as the reservoir of organic pollutants, thus can be used as natural archives to provide comprehensive information of historical OCP usage records (Lebeuf and Nunes 2005; Yang et al. 2010). On the other hand, OCPs in sediments undergo natural diffusion and attenuation processes, resulting in a secondary distribution pattern, that is more dependent on various factors, such as time, hydrodynamic condition and microbial activity compared to the primary source (Jia et al. 2010; Dong et al. 2015; Kang et al. 2016; Wang et al. 2020). There were a number of studies focused on interpreting the spatial distribution pattern of OCPs in surface sediments (Helm et al. 2011; 
Li et al. 2017; Lv et al. 2020), however, limited data are available regarding the environment fate of OCP residues in various subsurface environments, such as soil-groundwater system (Pan et al. 2019) and lakshore wetland where mixing of lake water and phreatic water occurs in shallow sediments. creating unique biogeochemical conditions for pollutant attenuation and migration.

In addition, microorganisms play a vital role in natural attenuation of organic pollutants, and they are sensitive to the synthetic compounds deposited in aquatic sediments with changes in their composition and activity (DeLorenzo et al. 2001). Several studies have demonstrated the responses of microbial community to different levels of OCPs in contaminated soils and in enhanced remediation treatments (Ali et al. 2019; Sun et al. 2019). Therefore, microbial community analysis could be conducted in line with pollutant analysis, to comprehensively reflect the ecological impacts of residual pollutant stresses in situ (Bissett et al. 2013; Azarbad et al. 2016).

Ya-Er lake is located in the middle and lower reaches of Yangtze River, and is the first sub-lake of Ya-Er lake surrounding by Gedian chemical plants, wherein once recognized as the hot-spot for industrial OCPs, including hexachlorocyclohexanes ( $\mathrm{HCHs}$ ), chlorobenzenes, $\mathrm{HCB}$, and their notorious derivates polychlorinated dibenzo-p-dioxins and dibenzofurans (PCDD/Fs) (Xu et al. 1994; Wu et al. 1997; 2001). As a countermeasure, the Ya-Er lake had been served as the largest oxidation pond system in Asia, which consisted of a series of five compartments ( 400 ha, from Pond No.1 to No.5) to treat around 80,000 tons wastewater daily from 1979 to 1991. In 2003 and 2004, the seriously polluted sludge in the idle oxidation ponds No. 1 to 3 were dredged and pumped into the northern backfill site at Pond No. 1, with the upper layer covered with clay. Today, the backfill site has turned into a reed mash area and for agriculture (Li et al. 2021). The present study has collected the subsurface sediments from Pond No.1 of Ya-Er lake and aims to: (1) determine the concentrations of 19 OCPs in the subsurface layers of the lakeshore backfill site and the lakebed; (2) examine the composition and potential sources of those OCPs; (3) evaluate the ecological impacts of dominant OCPs on sedimentary microbial communities.

\section{Materials And Methods}

\subsection{Sample collection}

Sediment samples were collected from five sampling sites with various depths at Ya-Er lake in July 2018. The geographic locations of the sampling sites are shown in Fig. 1. Duplicate sediment cores per site were taken by a portable sampler. Two lakeshore sites (YJF-landward and YJM-inward) were located at the cofferdam area, with an average sampling depth of $2.7 \mathrm{~m}$. In field, the subsurface sedimentary cores were divided into four sections from top to bottom, that is 0.5 0.9 $\mathrm{m}, 0.9-1.5 \mathrm{~m}, 1.5-2.0 \mathrm{~m}$ and 2.0-2.7 $\mathrm{m}$, respectively. The other three sampling sites (YJA, YJB and YJC) were at the lakebed of the abandoned oxidation pond No. 1, along the past wastewater flow from the inlet to outlet. The lakebed sediment cores were sectioned at 15-20 cm intervals to a depth of 40-60 cm. For each section, approximately $15 \mathrm{~g}$ of undisturbed sub-core sample was taken with a cut-off plastic syringe, placed in an aseptic centrifuge tube, and immediately stored in dry ice for microbial analysis. The remaining parallel samples were mixed thoroughly to form a composite sample for measurements of sediment physicochemical properties and OCPs.

\subsection{Chemicals}

Mixed standard samples of OCPs (including $o, p^{\prime}-\mathrm{DDE}, p, p^{\prime}-\mathrm{DDD}, p, p^{\prime}-\mathrm{DDT}, o, p^{\prime}-\mathrm{DDT}, \alpha-\mathrm{HCH}, \beta-\mathrm{HCH}, \gamma-\mathrm{HCH}, \delta-\mathrm{HCH}, \mathrm{HCB}$, aldrin, dieldrin, endrin, $\alpha$-endosulfan, $\beta$-endosulfan, trans-chlordane, cis-chlordane, methoxychlor, heptachlor, and heptachlor epoxide), recovery indicators (tetrachloroxylene (TCmX) and dechlorobiphenyls (PCB209) ), and the internal standard compound for quantitative analysis (pentachloronitrobenzene (PCNB)) were purchased from Ultra Scientific, USA. Dichloromethane (DCM), hexane and other organic solvents are chromatography pure. Silica gel and neutral alumina are 100 200 mesh, purchased from Qingdao Haiyang Chemical Co., and Sinopharm Medicine Holding Co., Ltd., 
China. Silica gel and neutral alumina were extracted in DCM for $48 \mathrm{~h}$, dried at room temperature, and then baked for $12 \mathrm{~h}$ at $180^{\circ} \mathrm{C}$ and $240^{\circ} \mathrm{C}$, respectively. After cooling to room temperature, add $3 \%$ deionized water of its mass to reduce the activity, and store it in a drying dish for later use after balancing. Anhydrous sodium sulfate was purchased from Sinopharm Medicine Holding Co., Ltd., China. It was roasted in muffle furnace at $450{ }^{\circ} \mathrm{C}$ for 4 hours and stored in a sealed container for reserve after drying.

\subsection{Extraction and instrument analysis of OCPs in sediment}

The OCPs were extracted from the freeze-dried and screened (100 mesh) sediment samples and analyzed according to USEPA approved technique under Method 8080A (Huang et al. 2018). In brief, $10.000 \mathrm{~g}$ of sediment sample was spiked with 20 ng recovery indicators (including TCmX and PCB209) and mixed with anhydrous sodium sulfate. The sample was extracted with DCM in Soxhlet extractor for $24 \mathrm{~h}$. At the same time, activated copper granules were added to the collection flask to remove elemental sulfur. The sediment extract was concentrated to $2 \mathrm{~mL}$ by rotary evaporation, then purified and separated by a chromatography column containing deactivated silica gel/alumina (V/V=2:1), eluted with 30 $\mathrm{mL}$ of $\mathrm{DCM} / \mathrm{n}$-hexane $(\mathrm{V} / \mathrm{V}=2: 3)$. The eluate solution was further concentrated to $0.5 \mathrm{~mL}$ by rotary evaporation and transferred to a $2 \mathrm{~mL}$ cell bottle. It was blown to $200 \mu \mathrm{L}$ with soft, high-purity nitrogen. Finally, $20 \mathrm{ng}\left(4 \mu \mathrm{L} \mathrm{of} 5 \mathrm{mg} \mathrm{L}^{-1}\right)$ of internal standard PCNB was added and stored at $-20^{\circ} \mathrm{C}$, prior to instrumental analysis.

The identification and quantification of OCPs were performed on a gas- chromatograph (Agilent7890A, US) equipped with a Ni electron capture detector (GC-ECD). Capillary column (HP-5, $30 \mathrm{~m} \times 0.32 \mathrm{~mm} \times 0.25 \mathrm{~m}$ ) was applied. Carrier gas was high purity nitrogen ( $\geq 99.999 \%$ ) with constant current of $2.5 \mathrm{~mL} \mathrm{~min}^{-1}$ The injector and detector temperatures were $290{ }^{\circ} \mathrm{C}$ and $300{ }^{\circ} \mathrm{C}$, respectively. The oven temperature was initiated at $100^{\circ} \mathrm{C}$ (held for $1 \mathrm{~min}$ ) and increased to $200{ }^{\circ} \mathrm{C}$ at $4{ }^{\circ} \mathrm{C} \min ^{-1}, 230{ }^{\circ} \mathrm{C}$ at $2{ }^{\circ} \mathrm{C} \mathrm{min}^{-1}$, and finally $280^{\circ} \mathrm{C}$ at $8{ }^{\circ} \mathrm{C} \mathrm{min}-1$ (held for $15 \mathrm{~min}$ ). The detection limit of OCPs ranged from 0 . 00 0. $59 \mathrm{ng} \mathrm{g}^{-1}$, and the recovery rate were $71 \% \sim 106 \%$.

\subsection{Microbial community analysis}

Microbial community structure was characterized by ester-linked fatty acid methyl ester (EL-FAME) analysis (Schutter and Dick 2000). The extraction and quantification procedures of EL-FAMEs were mainly performed according to the previous report (Wang and Tam 2012). Quantification of FAMEs was carried out using a Thermo Scientific Trace 1300 Gas Chromatograph and ISQ LT Mass Spectrometer (GC-MS) equipped with a $30 \mathrm{~m}$ DB-5MS capillary column. The injector temperature was $250^{\circ} \mathrm{C}$; in splitless mode; with helium carrier gas flow velocity of $0.8 \mathrm{~mL} \mathrm{~min}^{-1}$. The oven temperature was initially set at $50^{\circ} \mathrm{C}$ (held for $2 \mathrm{~min}$ ), increased at $50{ }^{\circ} \mathrm{C} \mathrm{min}-1$ to $150{ }^{\circ} \mathrm{C}$ (held for $2 \mathrm{~min}$ ), then at $2.5^{\circ} \mathrm{C}$ $\mathrm{min}^{-1}$ to $195^{\circ} \mathrm{C}$ (held for $3 \mathrm{~min}$ ) and a further increase at $2.5^{\circ} \mathrm{C} \mathrm{min}-1$ to $240^{\circ} \mathrm{C}$ (held for $5 \mathrm{~min}$ ). The whole program lasted for $50 \mathrm{~min}$. The MS detector was operated in electron-impact ionization (EI) in selective ion monitoring (SIM) mode. The quadrupole and ion-source temperatures were held at $230{ }^{\circ} \mathrm{C}$ and $280{ }^{\circ} \mathrm{C}$, respectively. Fatty acid peaks were identified using Bacterial Acid Methyl Esters CP Mixture (Matreya LLC.). A standard fatty acid nomenclature, e.g., A:BwC, was adopted (Vestal and White 1989).

\subsection{Statistical analysis}

A parametric one-way analysis of variance (ANOVA), followed by Tukey's multiple comparison test, was used to reveal any significant differences in OCP concentrations among sampling sites at $\mathrm{P} \leq 0.05$. A principal component analysis (PCA) using Varimax rotation was adopted to identify the potential sources of OCPs, that responsible for the variation in their distribution profiles (Larsen and Baker 2003). The contribution of pollution sources is quantified using the absolute principal component scores-multiple linear regression (APCS-MLR) receptor model (Haji Gholizadeh et al. 2016; Zhang et al. 2020). These above statistical tests were performed using the SPSS 24.0 software (SPSS Inc., Chicago, IL, USA) . Furthermore, a constrained ordination technique, redundancy analysis (RDA), was used to examine the relationships 
between the dominant OCP pollutants and microbial FA species by CANOCO 5.0 from Microcomputer Power (Ithaca, NY, USA).

\section{Results}

\subsection{Concentration and distribution of OCPs in the subsurface sediments}

The total concentrations of the 19 OCPs in the subsurface sediments were in the range of 29.8-941.8 ng g-1 $\mathrm{dw}^{\text {, with a }}$ mean value of $193.3 \mathrm{ng} \mathrm{g}^{-1}$ (Table 1). The mean concentrations of three dominant OCP classes were HCB (169.4 $\mathrm{ng} \mathrm{g}^{-}$ $\left.{ }^{1}\right)>\Sigma \mathrm{HCHs}\left(15.0 \mathrm{ng} \mathrm{g}^{-1}\right)>$ LDDTs $\left(4.8 \mathrm{ng} \mathrm{g}^{-1}\right)$, accounting for $26.5 \%-97.4 \%, 1.8 \%-51.5 \%$, and $0.4 \%-15.5 \%$ of the total OCPs, respectively. The mean concentrations of the other classes of OCPs were methoxychlor $\left(1.8 \mathrm{ng} \mathrm{g}^{-1}\right)>\Sigma \mathrm{CDs}\left(1.0 \mathrm{ng} \mathrm{g}^{-}\right.$ $\left.{ }^{1}\right)>\sum$ HTs $\left(0.82 \mathrm{ng} \mathrm{g}^{-1}\right)>\sum$ Drins $\left(0.3 \mathrm{ng} \mathrm{g}^{-1}\right)>\sum$ ESs $\left(0.2 \mathrm{ng} \mathrm{g}^{-1}\right)$, all together accounting for $0.4 \%-5.4 \%$ of the total OCPs in most of the samples, whereas high proportions of these minor OCPs were found in the shallow subsurface samples (F1$10.3 \%$ and $\mathrm{M} 1-12.3 \%)$, and the deepest layer of landward site F (F4-30.1\%) from the lakeshore.

The detection rates of the 19 OCPs varied from 44.4\%-100.0\% (Table 1). Eight OCPs were detected in all the samples, namely $\mathrm{HCB}, \mathrm{a}-, \beta-$, and $\delta-\mathrm{HCH}$ isomers, $p, p^{\prime}$-DDE, trans-chlordane (TC), cis-chlordane (CC) and heptachlor-epoxide. It was noted that $p, p^{\prime}$-DDT exhibited the lowest detection rate, and was mainly detected in the lakeshore samples. Likewise, $o, p^{\prime}$ DDT and $p, p^{\prime}$-DDD had higher detection rates in the lakeshore compared to the lakebed samples.

The coefficients of variation (CV) of $\mathrm{HCB}, \mathrm{a}-\mathrm{HCH}, \mathrm{y}-\mathrm{HCH}$, all DDTs except $p, p^{\prime}$-DDE were all over $140 \%$, indicating great spatial heterogeneity among samples. From Fig. 2, there were much greater site-specific variations between the lakeshore sites (YJF and YJM) than those in the lakebed sites (YJA\&B\&C or YJS). YJM exhibited the hotspots of HCB, with an average value of $495.2 \mathrm{ng} \mathrm{g}^{-1}$, significantly higher than those in YJF $\left(75.4 \mathrm{ng} \mathrm{g}^{-1}\right)$ and YJS $\left(76.6 \mathrm{ng} \mathrm{g}^{-1}\right)(P<0.01)$. Moreover, the residual levels of HCB greatly increased with depth by an order of magnitude from M1 to M4, and nearly doubled from F1 to F3. By contrast, YJF harbored the highest residual levels of HCHs and DDTs (27.9 and $\left.11.2 \mathrm{ng} \mathrm{g}^{-1}\right)$, followed by YJM (15.0 and $4.9 \mathrm{ng} \mathrm{g}^{-1}$ ) and YJS (9.9 and $\left.2.2 \mathrm{ng} \mathrm{g}^{-1}\right)$. The concentration of HCHs and DDTs generally reached their peak values in the 0.9-2.0 m deep layers of the lakeshore sites (i.e., F2, F3 and M3). Besides, the sitespecific variations for the other OCPs were relatively small and insignificant.

\subsection{Risk assessment of OCPs in the subsurface sediments}

Two widely used sediment quality guidelines, recommended by US National Oceanic and Atmospheric Administration (NOAA 1999) and Canadian Council of Ministers of the Environment (CCME 2002), were applied to evaluate the possible ecotoxicological risk of OCPs in the study sites (Table 2). Both guidelines showed the highest risk for $\beta$ - $\mathrm{HCH}$, as all the sampling sites had concentrations above its ERM and PEL values. High risks of HCB, $a-, \gamma-$, and $\delta-H C H s$ were also indicated, with $94 \%, 83 \%, 76 \%$ and $83 \%$ of the sites above their respective ERL values, respectively. Notably, only YJB in the centre of the pond showed little risk of HCB and HCHs. As for DDTs, all the sampling sites had the concentrations below their ERM values, and only $6 \%$ of the sampling sites (at either F2 or F3) had the concentrations above PELs for $0, p^{\prime}$-DDT, $p, p^{\prime}$-DDT and $p, p^{\prime}$-DDE. $39 \%, 6 \%$ and $50 \%$ of the sampling sites had the concentrations between TELs and PELs for $p, p^{\prime}$-DDT, $p, p^{\prime}$-DDD and $p, p^{\prime}$-DDE, indicating the site-specific moderate risks at the lakeshore. By contrast, $78 \%$ and $94 \%$ of the sampling sites had the concentrations below TELs for $0, p^{\prime}$-DDT and $p, p^{\prime}$-DDD. As for those minor OCPs, 100\%, 78\%, $100 \%, 100 \%$ and $100 \%$ of the sampling sites had the concentrations below TELs for heptachlor, heptachlor-epoxide, $\Sigma$ Chlordane, dieldrin and endrin, which exhibited low possibilities to have an adverse effect on sediment dwelling organisms. However, $61 \%, 78 \%$ and $67 \%$ of the sampling sites had the concentrations between ERLs and ERMs for $\Sigma$ Chlordane, dieldrin and endrin, which need further attention. 


\subsection{Source and fate analysis}

\subsubsection{Composition of representative OCPs}

Composition differences of $\mathrm{HCH}$ isomers indicated three trends (Fig. 3). First is the predominant $\mathrm{HCH}$ isomers changed from $\mathrm{a}-\mathrm{HCH}$ and $\mathrm{\gamma}-\mathrm{HCH}$ in the lakeshore sediments below the 1 st layer $(>0.9 \mathrm{~m})$ except $\mathrm{F} 4$ to $\beta-\mathrm{HCH}$ in the lakebed sediments (0.1-0.4 m). Second, distinctly high ratios of $\mathrm{a}$ - to $\mathrm{\gamma}-\mathrm{HCH}$ were observed in the shallow subsurface samples at F1-13.6, M1-9.3 and A1-4.9, respectively. As for their respective deeper layers, the ratios of a- to $\mathrm{Y}-\mathrm{HCH}$ in F2-F4 (around 3) were also much higher than those in M2-M4 and YJS except A1 (all around 1). Third, the centre lakebed sediments YJB showed distinctly high ratios of $\beta-\mathrm{HCH} /(\mathrm{a}-\mathrm{HCH}+\gamma-\mathrm{HCH})$ (almost 10), while this ratio was less than 1 in those heavily polluted layers from the lakeshore (F2, F3, M2-M4). The distribution percentages of $\mathrm{HCH}$ isomers could be thus divided into three types: I. Lakeshore sediments below $0.9 \mathrm{~m}$ except F4 containing $\mathrm{a}-\mathrm{HCH}(47 \% \pm 12 \%)>\gamma-\mathrm{HCH}(30 \% \pm 11 \%)>\beta-\mathrm{HCH}$ $(15 \% \pm 5 \%)>\delta-\mathrm{HCH}(9 \% \pm 3 \%)$; Il. F1, M1 and F4 containing $\beta-\mathrm{HCH}(59 \% \pm 6 \%)>\mathrm{a}-\mathrm{HCH}(29 \% \pm 7 \%)>\delta-\mathrm{HCH}(7 \% \pm 2 \%)>\gamma^{-}$ $\mathrm{HCH}(5 \% \pm 3 \%)$; III. Lakebed sediments (YJS) containing $\beta-\mathrm{HCH}(63 \% \pm 20 \%)>\mathrm{a}-\mathrm{HCH}(13 \% \pm 11 \%)>\gamma-\mathrm{HCH}(12 \% \pm 11 \%)>\delta-$ $\mathrm{HCH}(12 \% \pm 8 \%)$.

The average percentages of the parent DDTs were significantly higher in the lakeshore sediments $(48 \% \pm 8 \%)$ and at A1$66 \%$ compared to those in the other lakebed sediments $(17 \% \pm 2 \%)$, where $p, p^{\prime}$-DDT was hardly detected. $o, p^{\prime}$-DDT was mostly found more abundant than $p, p^{\prime}$-DDT in YJF and YJS, while the ratios of $o, p^{\prime}$-DDT to $p, p^{\prime}$-DDT were only 0.2-0.6 in YJM samples. The ratios of DDT metabolites (DDE+DDD) to DDTs were extremely high (5-8) in the lakebed sediments except A1, with $p, p^{\prime}-\mathrm{DDE}$ as the dominant DDT metabolite (68\% $\left.\pm 17 \%\right)$, followed by $p, p^{\prime}-\mathrm{DDD}(22 \% \pm 13 \%)$. By contrast, the average percentages of $p, p^{\prime}$-DDE and $p, p^{\prime}$-DDD in the lakeshore sediments were $34 \% \pm 15 \%$ and $18 \% \pm 13 \%$, respectively. The raios of DDD/DDE were generally less than 1.0, except for that at F4 (2.6).

In addition, the ratios of TC to CC were mostly less than 0.76 , indicating the historical inputs of technical chlordance (Li et al. 2006), except for F3 (1.3), M3 (2.1) and M2 (0.8). The ratios of a- to $\beta$-Endosulfan were far less than 2.33 (Rice et al. 1997), suggesting no new input for endosulfans in the study site.

\subsubsection{PCA analysis for source identification}

Principal component analysis (PCA) was performed in this study to further identify the OCP sources. Five principal components (PCs) with eigenvalues over 1 were extracted, accounting for $80.8 \%$ of the total variance (Table 3 ). PC1 was predominately weighted by three $\mathrm{HCH}$ isomers $(\delta-, \mathrm{a}-$ and $\mathrm{y}-\mathrm{HCH}), p, p^{\prime}-\mathrm{DDE}$, its parent $p, p^{\prime}$-DDT, and trans-chlordane, and accounted for $27.6 \%$ of the total variance. $\mathrm{HCHs}$ were frequently reported as the main products of the previous local chemical plant from 1962-1987 (Xu et al. 1994). These compounds were representative dominant OCPs detected below the 1st subsurface layers of lakeshore sediments, especially at F3 and F2, but not at F4 (Fig. 4), indicating that they were from the historically polluted dredged sediments but did not extend to the 4th layer at YJF. PC2 was predominately composed by heptachlor-epoxide, its parent heptachlor, aldrin, methoxychlor and $\beta$-endosulfan, and accounted for $23.4 \%$ of the total variance. This cluster of OCPs were associated with their recent usage as alternative of DDTs dated after 1990s in agricultural activities (Niu et al. 2016). They were found dominant in the 1st subsurface layers at F1, M1, A1, and at F4 (where was once the surface layer before being covered by the dredged sediments), and decreased in the order of YJF>YJS>YJM. PC3 was heavily weighted by $p, p^{\prime}$-DDD, $o, p^{\prime}$-DDT, followed by cis-chlordane and a-endosulfan, responsible for $12.3 \%$ of the total variance. This profile was indicative of usage of dicofol, chlordane and endosulfan (Qiu et al. 2005), and most typical at F2 besides those shallow 1st subsurface layers, when comparing with the contribution pattern of PC2. PC4 was responsible for $9.5 \%$ of the total variance. This factor was positively weighted by $\mathrm{HCB}$ and endrin, and negatively by $\beta-\mathrm{HCH}$. $\mathrm{HCB}$ and $\beta-\mathrm{HCH}$ were among the most persistent OCPs in the environment (Willett et al. 1998), with endrin showing similar source. Notably, HCB was largely retained in M2-M4 at YJM, where $\beta$ - 
$\mathrm{HCH}$ had the lowest levels and relative proportions. PC5 was weighted by deildrin, and responsible for $8.1 \%$ of the total variance.

\subsubsection{Contribution of pollution sources}

Based on the pollution sources identified by PCA, an APCS-MLR model was employed to establish the function relationship between pollution sources and concentrations of each OCP variable, for calculation of the source contributions. The linear relationships between the predicted and the observed values of each OCP showed good consistency, with $\mathrm{R}^{2}$ values ranging from 0.65 to 0.94 . Results of source apportionment with APCS-MLR model are shown in Fig. 5. Average contributions of different pollution sources of OCPs in the subsurface sediments of Ya-Er lake were $27.2 \%, 14.7 \%, 0.9 \%, 14.3 \%$ and $3.1 \%$ for historical industrial input (S1), recent agricultural input (S2), historical mixture input (S3), persistent residuals (S4) and diedrin (S5), respectively. Apart of these sources, the average contribution of unidentified source (B) was highest, up to $39.9 \%$, which was much higher in most of the lakebed sediments compared to the lakeshore ones (Fig. 5A). Notably, the contributions of this unidentified source varied greatly among OCPs, which were polarized between the more easily-degraded or transformed OCPs like $o, p^{\prime}$-DDT, trans-chlordane and aldrin ( $<5 \%)$ and those more persistent ones including $p, p^{\prime}$-DDD, cis-chlordane, deidrin, $\beta$-HCH and HCB (42\%-76\%) (Fig. 5B). Thus, the unidentified source could be interpreted as source of biodegradation.

\subsection{Ecological impacts of OCPs on microbial community}

Microbial EL-FAME profile of the 18 sediment samples (with duplicates or triplicates) was examined to explore the ecological impacts of OCPs on microbial community structure. The sample scatter plot based on PCA analysis of the microbial EL-FAME profile resembled OCP distribution pattern, with the first two PCs explained $71.9 \%$ of the total variance. The differences of microbial community structure among lakeshore samples from YJF and YJM were much greater than those among lakebed samples, in line with the detected gradients in OCP levels. Redundancy analysis (RDA) further confirmed a significant relationship between the EL-FAME profile and nine dominant OCPs, including HCB, four $\mathrm{HCH}$ isomers and four DDTs. The first and all canonical axes contributed to explain 52.0 and $78.4 \%$ of the total variance in microbial species data, with F-values of $8.7(P=0.014)$ and $3.2(P=0.008)$, respectively. From the RDA plot of environmental variables, $p, p^{\prime}-\mathrm{DDT}, \mathrm{a}-\mathrm{HCH}$, and $\delta-\mathrm{HCH}$, were highly, positively correlated with the first axis, followed by $p, p^{\prime}$ $\mathrm{DDE}, \mathrm{HCB}$ and $\mathrm{\gamma}-\mathrm{HCH}$ (Table 4 and Fig. 6 ). They all showed significant simple effects on microbial community structure $\left(P<0.05\right.$, when individually tested). However, $p, p^{\prime}$-DDT and HCB were selected in the first and second place to explain $39.1 \%$ and $15.1 \%$ of the total variance, respectively, after the conditional effects of the three $\mathrm{HCH}$ isomers and $p, p^{\prime}$-DDE decreased remarkably, indicating strong mutual correlations among these OCPs of the same origin-S1. Meanwhile, $o, p^{\prime}-$ DDT, also positively correlated with the second axis, was identified as the third important environmental factor affecting microbial community structure $(8.8 \%, \mathrm{P}=0.01)$. These results indicate HCB and $o, p^{\prime}$-DDT had posed independent influences on microbial community composition in addition to $p, p^{\prime}$-DDT.

The distribution of microbial FAME biomarkers was highly correlated to the OCP level and composition. Hydroxyl fatty acids (FAs), indicative of Pseudomonas, Actinomycetales, and Mycobacterium (Zelles 1999), were only enriched in those heavily-polluted dredged sediments at lakeshore sites (F2\&F3, M2-M4) (Fig. 6A\&B). In particular, enriched 18:2w9, monounsaturated fatty acid (MUFA) of 18:1 $\omega 9 c$, and cyclopropane FA of cy 19:0, were detected at F2 with the highest level of DDTs, suggesting a variety of microbial functional groups, i.e., fungi, aerobic and anaerobic gram-negative bacteria were actively involved to degrade DDTs at this site. High ratios of cis/trans 18:1 $\omega 9$ and MUFA/Branch corresponded to the high levels of $o, p^{\prime}$-DDT and $p, p^{\prime}$-DDD (Fig. 6C). By contrast, branched FAs (i15:0, a15:0, i16:0 and i17:0) indicative of gram-positive bacteria were dominant in the lightly polluted lakebed sediments, but with high proportions of refractory OCPs like $\beta-\mathrm{HCH}$. 


\section{Discussion}

In this study, the pollution feature of 19 OCPs in subsurface sediments from the abandoned oxidation pond of Ya-Er lake was assessed over a decade after its dredging treatment. HCB and HCHs from the historical industrial discharge were still served as the two dominant OCPs in this pond. Although "hot spots" of HCB and HCHs mostly detected in the lakeshore sediment cores, the residual concentrations of HCB in lake subsurface sediments were around 1/1000 to 1/50 of the historical data recorded in 1991-1994, but the maximum and mean concentrations of $\Sigma \mathrm{HCHs}$ were just a fraction of the reported values at Pond No. 1-3 before dredging (Table 5). These findings suggest that HCB and HCHs in the dredged sediments underwent natural attenuation in different degrees. Notably, the levels of $\mathrm{HCB}$ and $\Sigma \mathrm{HCHs}$ in the lakebed subsurface sediments remained tens and several times of the values of the surface sediments at Pond No. 1-3 in 2009 after dredging, while $\Sigma \mathrm{HCH}$ s were ten times higher than the values detected in the surrounding soils (Liu et al. 2011; Liu et al. 2017). By contrast, the concentration range and mean values of $\Sigma$ DDTs in the subsurface sediments were comparable or slightly lower than those in the surface sediments of Pond No. 1-5 in 2009, while EDDTs in both surface and subsurface sediments were much lower than those in the surrounding soils. This suggests that DDTs in Ya-Er Lake were mainly originated from the agricultural non-point sources, which were reported most dominant in lake basins along the Yangze river in China like Taihu, Chaohu, Poyang, and etc. (Lu et al. 2012; Li et al. 2015; Zhao et al. 2017). Results of risk assessment and impacts of OCPs on microbial community both indicated the dominant HCB representative of historical industrial residuals, has lower ecological impacts compared to DDTs and HCHs, so the control of technical products like $p, p^{\prime}$-DDT, $o, p^{\prime}$-DDT and $\mathrm{a}-\mathrm{HCH}$ should give priority concern in this site.

Spatial variations of OCP concentrations were remarkable in this study, especially for the lakeshore sites. The large heterogeneity of OCP levels in depth could be related to the dredged activities conducted from Pond No.1 to No.3 by sequence. But the heterogeneity of OCP composition between the landward and inward sites (YJF and YJM) might be of complex causes, including origin of the polluted sediments, particle size distribution and feasible natural attenuation processes under different hydrologic conditions and pollution stress from combined pollutants like Hg (Dong et al. 2015; Yang et al. 2015; Wu et al. 2016). This distinct discrepancy in OCP composition between the two lakeshore sites indicated weak exchange capability of the lipophilic OCPs adsorbed on sediment particles which had low mobility in the phreatic water through lateral dispersion. Nevertheless, the profile of $\mathrm{HCHs}$, DDTs and chlordanes in the shallow subsurface layer at lakebed site (A1) closest to the lakeshore more closely resembled those in the deep subsurface layers at inward lakeshore site (M2-M4) than the other lakebed sites (Fig. 3). This might be attributed by the potential interaction between lake water and phreatic water in the lake hyporheic zone when seasonal flood and storm run off occurred (Hester et al. 2013). It is thus necessary to combine hydrogeolocial survey and modeling to elaborate this process and quantify the exchange flux for further risk assessment.

The multivariate correlation analysis of the microbial and OCP data helps to directly evaluate the ecological impacts of OCPs in lake subsurface sediments. The most influential OCP variables, including $p, p^{\prime}-\mathrm{DDT}, \mathrm{a}-\mathrm{HCH}, \delta-\mathrm{HCH}, \mathrm{and} p, p^{\prime}-\mathrm{DDE}$, were generally more easily-degraded by a variety of microorganisms including both bacteria and fungi (Subba-Rao et al. 1985; Concha-Graña et al. 2006). So they might be more impactful to induce the shifts of microbial communities than those more persistent ones like $\beta-\mathrm{HCH}$ and $\mathrm{HCB}$ (Brahushi et al. 2004). Previous studies on aerobic OCP-degrading bacteria have shown that many gram-negative bacterial genera of Alcaligenes, Sphingobacterium, and Sphingomonas were capable of degrading DDT and $\mathrm{HCH}$, while only one gram-positive bacterial genus of Nocardioides was reviewed involving the degradation of HCB (Nagata et al. 2016). The indication of potential microbial functional groups by FAME biomarkers showed a consistent result regarding the dominant OCP distribution. Moreover, the shift of dominant microbial groups could be used as good indicator to monitor the natural bio-attenuation process, during which microbial specialists capable of utilizing different types of organic compounds took the predominance in turn, in the order of their easiness of degradation. So the enriched gram-negative bacteria at F2 would be actively involved in the degradation of DDTs, while the microbial communities dominant with gram-positive bacteria were restored or screened out after those 
readily-degradable carbon sources were exhausting, similar to the microbial responses after oil spills (Kimes et al. 2014). However, as FAME biomarkers could not identify microbial functional groups at species level, further studies based on genotypic biomarkers, such as 16S rRNA and dehalogenase genes, would be employed to provide insights on the key microbial species involved and their role in bio-attenuation of OCPs under natural environmental conditions.

\section{Conclusion}

The present study indicates the OCP contamination has been mitigated greatly in the Ya-Er lake 15 years after dredging treatment. The concentrations of $\mathrm{HCH}$ and DDTs were comparable to and/or lower to the values reported by previous studies on freshwater lakes. But a higher level of HCB was still found than the few reported values, especially in the hot spots distributed in 0.9-2.7 $\mathrm{m}$ deep layers in the lakeshore dump site. Source appointment analysis confirmed the main contributions of historical industrial input and its residuals at the lakeshore backfill site YJF and YJM, respectively. The relationship between OCP profile and microbial community structure was significant, with DDTs and HCHs being identified as more important OCP variables than HCB in affecting microbial communities in lake sediments. The other widely-concerned POPs like PCDD/Fs and PCBs, and concomitant heavy metals like mercury, lead and arsenic, were not determined in this study. It thus required further investigation regarding their combined effects on microbial community structure and diversity, as well as on other aquatic biota, for a comprehensive assessment of the ecological impacts of OCPs on-site, thus providing case-specific remediation strategies in this area.

\section{Declarations}

Acknowledgements The work described in this paper was supported by National Natural Science Foundation of China, No. 41977362 and No. 41630318); Research Program for Geological Processes, Resources and Environment in the Yangtze River Basin (CUGCJ1702). The authors would like to thank Prof. Liu Peng for his kind guidance in sample collection.

Author contribution Yafen WANG: Conceptualization, Methodology, Formal analysis, Writing-Review \& Editing, Funding acquisition, Supervision. Tao LIU: Writing-Original Draft, Methodology, Data curation, Formal analysis. Jincan TANG: Writing-Review \& Editing. Zhiwei XIONG: Collect samples, Microbial and OCP analyses. Liangchu SONG: Collect samples, Data curation. Teng MA: Funding acquisition, Project administration, Supervision.

Funding National Natural Science Foundation of China, No. 41977362 and No. 41630318); Research Program for Geological Processes, Resources and Environment in the Yangtze River Basin (CUGCJ1702).

Ethics approval and consent to participate Not applicable.

Consent for publication Not applicable.

Availability of data and materials All data generated and analysed during this study are included in the published article.

Competing interests The authors declare that they have no competing interests.

\section{References}

1. Ali N, Khan S, Li Y, Zheng N, Yao H (2019) Influence of biochars on the accessibility of organochlorine pesticides and microbial community in contaminated soils. Sci. Total Environ. 647, 551-560.

https://doi.org/10.1016/j.scitotenv.2018.07.425

Page $9 / 25$ 
2. Anderson AM, Conkle LJ, Pacheco P, Gan J (2013) Use of hydroacoustic measurements to characterize bottom sediments and guide sampling and remediation of organic contaminants in lake sediments. Ecotoxicol. Environ. Saf. 458-460, 117-124. https://doi.org/10.1016/j.scitotenv.2013.04.009

3. Azarbad H, van Gestel CAM, Niklińska M, Laskowski R, Röling WFM, van Straalen NM (2016) Resilience of soil microbial communities to metals and additional stressors: DNA-based approaches for assessing "stress-on-stress" responses. Int. J. Mol. Sci. 17, 933. https://doi.org/10.3390/ijms17060933

4. Barakat AO, Khairy M, Aukaily I (2013) Persistent organochlorine pesticide and PCB residues in surface sediments of Lake Qarun, a protected area of Egypt. Chemosphere 90, 2467-2476.

https://doi.org/10.1016/j.chemosphere.2012.11.012

5. Bhattacharya B, Sarkar SK, Mukherjee N (2003) Organochlorine pesticide residues in sediments of a tropical mangrove estuary, India: implications for monitoring. Environ. Int. 29, 587-592. https://doi.org/10.1016/S01604120(03)00016-3

6. Bissett A, Brown MV, Siciliano SD, Thrall PH (2013) Microbial community responses to anthropogenically induced environmental change: towards a systems approach. Ecol. Lett. 16, 128-139. https://doi.org/https://doi.org/10.1111/ele.12109

7. Brahushi F, Dörfler U, Schroll R, Munch JC (2004) Stimulation of reductive dechlorination of hexachlorobenzene in soil by inducing the native microbial activity. Chemosphere 55, 1477-1484. https://doi.org/10.1016/j.chemosphere.2004.01.022

8. Brevik EM, Grande M, Knutzen J, Polder A, Skaare JU (1996) DDT contamination of fish and sediments from Lake Ørsjøen, Southern Norway: Comparison of data from 1975 and 1994. Chemosphere 33, 2189-2200. https://doi.org/10.1016/0045-6535(96)00307-4

9. Buah-Kwofie A, Humphries MS (2017) The distribution of organochlorine pesticides in sediments from iSimangaliso Wetland Park: Ecological risks and implications for conservation in a biodiversity hotspot. Environ. Pollut. 229, 715 723. https://doi.org/ 10.1016/j.envpol.2017.07.031

10. CCME (Canadian Council of Ministers of the Environment) (2002) Canadian sediment quality guidelines for the protection of aquatic life. In: Canadian Environmental Quality Guidelines. Canada.

11. Clément B, Vaille G, Moretto R, Vernus E, Abdelghafour M (2010) Effects of a physico-chemical treatment of a dredged sediment on its ecotoxicity after discharge in laboratory gravel pit microcosms. J. Hazard. Mater. 175, 205215. https://doi.org/ 10.1016/j.jhazmat.2009.09.150

12. Concha-Graña E, Turnes-Carou MI, Muniategui-Lorenzo S, López-Mahía P, Prada-Rodríguez D, Fernández- Fernández $\mathrm{E}$ (2006) Evaluation of $\mathrm{HCH}$ isomers and metabolites in soils, leachates, river water and sediments of a highly contaminated area. Chemosphere 64, 588-595. https://doi.org/10.1016/j.chemosphere.2005.11.011

13. Dahm CN, Grimm NB, Marmonier P, Valett HM, Vervier P (1998) Nutrient dynamics at the interface between surface waters and groundwaters. Freshw. Biol. 40, 427-451. https://doi.org/10.1046/j.1365-2427.1998.00367.x

14. DeLorenzo ME, Scott GI, Ross PE (2001) Toxicity of pesticides to aquatic microorganisms: A review. Environ. Toxicol. Chem. 20, 84-98. https://doi.org/10.1002/etc.5620200108

15. Dirbaba NB, Li S, Wu HJ, Yan X, Wang J (2018) Organochlorine pesticides, polybrominated diphenyl ethers and polychlorinated biphenyls in surficial sediments of the Awash River Basin, Ethiopia. PLoS One 13, 20. https://doi.org/10.1371/ journal.pone.0205026

16. Dong WH, Zhang P, Lin XY, Zhang Y, Tabouré A (2015) Natural attenuation of 1,2,4-trichlorobenzene in shallow aquifer at the Luhuagang's landfill site, Kaifeng, China. Sci. Total Environ. 505, 216-222. https://doi.org/10.1016/j.scitotenv.2014.10.002

Page $10 / 25$ 
17. Gomes HI, Dias-Ferreira C, Ribeiro AB (2013) Overview of in situ and ex situ remediation technologies for PCBcontaminated soils and sediments and obstacles for full-scale application. Sci. Total Environ. 445-446, 237-260. https://doi.org/10.1016/j.scitotenv. 2012.11.098

18. Haji Gholizadeh M, Melesse AM, Reddi L (2016) Water quality assessment and apportionment of pollution sources using APCS-MLR and PMF receptor modeling techniques in three major rivers of South Florida. Sci. Total Environ. 566-567, 1552-1567. https://doi.org/10.1016/j.scitotenv.2016.06.046

19. Helm PA, Milne J, Hiriart-Baer V, Crozier P, Kolic T, Lega R, Chen T, MacPherson K, Gewurtz S, Winter J, Myers A, Marvin CH, Reiner EJ (2011) Lake-wide distribution and depositional history of current- and past-use persistent organic pollutants in Lake Simcoe, Ontario, Canada. J. Gt. Lakes Res. 37, 132-141. https://doi.org/10.1016/ j.jglr.2011.03.016

20. Hester ET, Young KI, Widdowson MA (2013) Mixing of surface and groundwater induced by riverbed dunes: Implications for hyporheic zone definitions and pollutant reactions. Water Resour. Res. 49, 5221-5237. https://doi.org/https://doi.org/10.1002/wrcr.20399

21. Huang HF, Zhang Y, Chen W, Chen WW, Yuen DA, Ding Y, Chen YJ, Mao Y, Qi SH (2018) Sources and transformation pathways for dichlorodiphenyltrichloroethane (DDT) and metabolites in soils from Northwest Fujian, China. Environ. Pollut. 235, 560-570. https://doi.org/10.1016/j.envpol.2017.12.071

22. Jayaraj R, Megha P, Sreedev P (2016) Organochlorine pesticides, their toxic effects on living organisms and their fate in the environment. Interdiscip. Toxicol. 9, 90-100. https://doi.org/10.1515/intox-2016-0012

23. Jia H, Liu L, Sun Y, Sun B, Wang D, Su Y, Kannan K, Li YF (2010) Monitoring and modeling endosulfan in Chinese surface soil. Environ. Sci. Technol. 44, 9279-9284. https://doi.org/10.1021/es102791n

24. Kang L, He QS, He W, Kong XZ, Liu WX, Wu WJ, Li YL, Lan XY, Xu FL (2016) Current status and historical variations of DDT-related contaminants in the sediments of Lake Chaohu in China and their influencing factors. Environ. Pollut. 219, 883-896. https://doi.org/10.1016/j.envpol.2016.08.072

25. Kimes NE, Callaghan AV, Suflita JM, Morris PJ (2014) Microbial transformation of the deepwater horizon oil spillpast, present, and future perspectives. Front. Microbiol. 5, 1-11. https://doi.org/10.3389/fmicb.2014.00603

26. Larsen RK, Baker JE (2003) Source apportionment of polycyclic aromatic hydrocarbons in the urban atmosphere: A comparison of three methods. Environ. Sci. Technol. 37, 1873-1881. https://doi.org/10.1021/es0206184

27. Lebeuf M, Nunes T (2005) PCBs and OCPs in sediment cores from the Lower St. Lawrence Estuary, Canada: Evidence of fluvial inputs and time lag in delivery to coring sites. Environ. Sci. Technol. 39, 1470-1478. https://doi.org/10.1021/es049051c

28. Li C, Huo S, Yu Z, Xi B, Yeager KM, He Z, Ma C, Zhang J, Wu F (2017) National investigation of semi-volatile organic compounds (PAHs, OCPs, and PCBs) in lake sediments of China: Occurrence, spatial variation and risk assessment. Sci. Total Environ. 579, 325-336. https://doi.org/10.1016/j.scitotenv.2016.11.097

29. Li C, Chen LF, He YJ, Liang Y, Wang YJ, Li FF, Gao W, Wang YW, Jiang GB (2021) Migration mechanism and risk assessment of chlorinated paraffins in highly polluted Ya'Er Lake area, China. Environ. Pollut. 281, 117015. https://doi.org/10.1016/ j.envpol.2021.117015

30. Li J, Zhang G, Qi SH, Li XD, Peng XZ (2006) Concentrations, enantiomeric compositions, and sources of HCH, DDT and chlordane in soils from the Pearl River Delta, South China. Sci. Total Environ. 372, 215-224. https://doi.org/10.1016/j.scitotenv. 2006.09.023

31. Liu M, Zhong JC, Zheng XL, Yu JH, Liu DH, Fan CX (2018) Fraction distribution and leaching behavior of heavy metals in dredged sediment disposal sites around Meiliang Bay, Lake Taihu (China). Environ. Sci. Pollut. Res. 25, 9737-9744. https://doi.org/10.1007/s11356-018-1249-2 
32. Liu H, Liu M, Wu D, Zheng J, Zhan C, Zhang J, Yao R (2017) Pollution characteristics and health risk assessment of organochlorine pesticides in eastern Hubei province. J.Hubei Polytech. U. 33, 18-23.

https://doi.org/10.3969/j.issn.2095-4565.2017.03.005. (In Chinese)

33. Liu L, Wang L, Gao L, Li C, Zhang B, Li S, Huang W, Zhou X, Li Y (2011) Occurrence and distribution of organochlorine pesticides (OCPs) in surface sediments of the Ya-er lake in Hubei province, China. Environ. Chem. 30, 1643-1649. (In Chinese)

34. Long ER, Macdonald DD, Smith SL, Calder FD (1995) Incidence of adverse biological effects within ranges of chemical concentrations in marine and estuarine sediments. Environ. Manage. 19, 81-97. https://doi.org/10.1007/bf02472006

35. Lu M, Zeng DC, Liao Y, Tong B (2012) Distribution and characterization of organochlorine pesticides and polycyclic aromatic hydrocarbons in surface sediment from Poyang Lake, China. Sci. Total Environ. 433, 491-7. https://doi.org/10.1016/ j.scitotenv.2012.06.108

36. Lv M, Luan X, Guo X, Liao C, Guo D, Miao J, Wu X, Zhou R, Liu D, Wang D, Zhao Y, Chen L (2020) A national-scale characterization of organochlorine pesticides (OCPS) in intertidal sediment of China: Occurrence, fate and influential factors. Environ. Pollut. 257, 113634. https://doi.org/10.1016/j.envpol.2019.113634

37. Lyall K, Croen LA, Sjödin A, Yoshida CK, Zerbo O, Kharrazi M, Windham GC (2017) Polychlorinated biphenyl and organochlorine pesticide concentrations in maternal mid-pregnancy serum samples: Association with autism spectrum disorder and intellectual disability. Environ. Health Perspect. 125, 474-480. https://doi.org/10.1289/ EHP277

38. Nagata Y, Tabata M, Ohtsubo Y, Tsuda M (2016) Biodegradation of organochlorine pesticides, in: Yates, M.V., Nakatsu, C.H., Miller, R.V., Pillai, S.D. (Eds), Manual of Environmental Microbiology, Fourth Edition. Washington, DC: ASM Press. pp. 5.1.2,1-30. https://doi.org/10.1128/9781555818821.ch5.1.2

39. Niu L, Xu C. Zhu S, Liu W (2016) Residue patterns of currently, historically and never-used organochlorine pesticides in agricultural soils across China and associated health risks. Environ. Pollut. 219, 315-322.

https://doi.org/10.1016/j.envpol.2016.10.060

40. NOAA ((National Oceanic and Atmospheric Administration) (1999) Sediment Quality Guidelines developed for the National Status and Trends Program. 1-12. http://www.coastalscience.noaa.gov/ publications/handler.aspx? key $=1527$

41. OMOE (Ontario Ministry of the Environment) (1993) Guidelines for the Protection and Management of Aquatic Sediment Quality in Ontario. https://doi.org/10.1093/iclqaj/ 18.2.494

42. Pan H, Lei H, He X, Xi B, Xu Q (2019) Spatial distribution of organochlorine and organophosphorus pesticides in soilgroundwater systems and their associated risks in the middle reaches of the Yangtze River Basin. Environ. Geochem. Health 41, 1833-1845. https://doi.org/10.1007/s10653-017-9970-1

43. Qiu X, Zhu T, Yao B, Hu J, Hu S (2005) Contribution of dicofol to the current DDT pollution in China. Environ. Sci. Technol. 39, 4385-4390. https://doi.org/10.1021/ es050342a

44. Qu C, Albanese S, Lima A, Hope D, Pond P, Fortelli A, Romano N, Cerino P, Pizzolante A, De Vivo B (2019) The occurrence of OCPs, PCBs, and PAHs in the soil, air, and bulk deposition of the Naples metropolitan area, southern Italy: Implications for sources and environmental processes. Environ. Int. 124, 89-97. https://doi.org/10.1016/ j.envint.2018.12.031

45. Rice CP, Chernyak SM, McConnell LL (1997) Henry's law constants for pesticides measured as a function of temperature and salinity. J. Agric. Food Chem. 45, 2291-2298. https://doi.org/10.1021/jf960834u

46. Schutter ME, Dick RP (2000) Comparison of fatty acid methyl ester (FAME) methods for characterizing microbial communities. Soil Sci. Soc. Am. J. 64, 1659-1668. https://doi.org/10.2136/sssaj2000.6451659x

Page $12 / 25$ 
47. Subba-Rao RV, Alexander M (1985) Bacterial and fungal cometabolism of 1,1,1-trichloro-2,2-bis(4chlorophenyl)ethane (DDT) and its breakdown products. Appl. Environ. Microbiol. 49, 509-516. https://doi.org/10.1128/AEM.49.3.509-516.1985

48. Sun G, Du Y, Yin JX, Jiang YZ, Zhang D, Jiang B, Li G, Wang H, Kong F, Su L, Hu J (2019) Response of microbial communities to different organochlorine pesticides (OCPs) contamination levels in contaminated soils. Chemosphere 215, 461-469. https://doi.org/10.1016/j.chemosphere.2018.09.160

49. Tsai WT (2010) Current Status and Regulatory Aspects of Pesticides Considered to be Persistent Organic Pollutants (POPs) in Taiwan. Int. J. Environ. Res. Public Health 7, 3615-3627. https://doi.org/10.3390/ijerph7103615

50. Vestal JR, White DC (1989) Lipid analysis in microbial ecology: quantitative approaches to the study of microbial communities. Bioscience 39, 535-541. .https://doi.org/10.2307/ 1310976

51. Wang L, Jia HL, Liu X, Sun, YQ, Yang M, Hong WJ, Qi H, Li YF (2013) Historical contamination and ecological risk of organochlorine pesticides in sediment core in northeastern Chinese river. Ecotoxicol. Environ. Saf. 93, 112-120. https://doi.org/10.1016/j.ecoenv.2013.04.009

52. Wang C, Hao Z, Feng Z, Zhang C, Gao J, Li Y, Yu W, Zou X (2020) Rapid changes in organochlorine pesticides in sediments from the East China sea and their response to human-induced catchment changes. Water Res. 169, 115225. https://doi.org/10.1016/ j.watres.2019.115225

53. Wang YF, Tam NFY (2012) Natural attenuation of contaminated marine sediments from an old floating dock Part II: changes of sediment microbial community structure and its relationship with environmental variables. Sci. Total Environ. 423, 95-103. https://doi.org/10.1016/j.scitotenv.2012.01.066

54. Wei L, Tadesse AW, Wang J (2019) Organohalogenated contaminants (OHCs) in surface sediments and water of east Dongting lake and Hong lake, china. Arch. Environ. Contam. Toxicol. 76, 157-170. https://doi.org/10.1007/s00244-018-0564-4

55. Willett KL, Ulrich EM, Hites RA (1998) Differential toxicity and environmental fates of hexachlorocyclohexane isomers. Environ. Sci. Technol. 32, 2197-2207. https://doi.org/ 10.1021/es9708530

56. Wu WZ, Schramm KW, Henkelmann B, Xu Y, Yediler A, Kettrup A (1997) PCDD/Fs,PCBs, HCHs and HCB in sediments and soils of Ya-Er lake area in China: Results on residual levels and correlation to the organic carbon and the particle size. Chemosphere 34, 191-202. https://doi.org/10.1016/S0045-6535(96)00351-7

57. Wu WZ, Xu Y, Schramm KW, Kettrup A (2001) Persistence of polychlorinated dibenzo-p-dioxins and dibenzofurans (PCDD/F) in Ya-Er Lake area, China. Environ. Int. 26, 323-326. https://doi.org/10.1016/S0160-4120(01)00007-1

58. Wu Y, Wang X, Ya M, Li Y, Hong H (2016) Distributions of organochlorine compounds in sediments from Jiulong River Estuary and adjacent Western Taiwan Strait: Implications of transport, sources and inventories. Environ. Pollut. 219, 519-527. https://doi.org/10.1016/j.envpol.2016.05.081

59. Xu Y, Wu W, Zhang Y, Zhang Y, Kettrup A (1999) Dynamics and long-term fate of residual hexachlorocyclohexane $(\mathrm{HCH})$ in various types of environment in Ya-Er lake area, China. Acta Hydrobiologica Sinica 23, 337-345. https://doi.org/10.3321/j.issn:1000-3207.1999.04.007 (In Chinese)

60. Xu Y, Zhang Y, Oxynos K, Schmitzer J, Kettrup A (1994) Hexachlorocyclohexane (HCH) Residues in Ya-Er Lake Area, China. Int. J. Environ. Anal. Chem. 57, 53-61. https://doi.org/10.1080/03067319408033101

61. Yang H, Battarbee RW, Turner SD, Rose NL, Derwent RG, Wu G, Yang R (2010) Historical Reconstruction of Mercury Pollution Across the Tibetan Plateau Using Lake Sediments. Environ. Sci. Technol. 44, 2918-2924. https://doi.org/10.1021/es9030408

62. Yang YY, Toor GS, Williams CF (2015) Pharmaceuticals and organochlorine pesticides in sediments of an urban river in Florida, USA. J. Soils Sediments 15, 993-1004. https://doi.org/10.1007/s11368-015-1077-7 
63. Zarull AM, Hartig Hj, Krantzberg G (2002) Ecological benefits of contaminated sediment remediation. Rev. Envion. Contam. Toxicol. 174, 1-18. https://doi.org/10.1007/ 978-1-4757-4260-2_1

64. Zelles L (1999) Fatty acid patterns of phospholipids and lipopolysaccharides in the characterisation of microbial communities in soil: a review. Biol. Fertil. Soils 29, 111-129. https://doi.org/10.1007/s003740050533

65. Zhang H, Cheng S, Li H, Fu K, Xu Y (2020) Groundwater pollution source identification and apportionment using PMF and PCA-APCA-MLR receptor models in a typical mixed land-use area in Southwestern China. Sci. Total Environ. 741, 140383. https://doi.org/10.1016/j.scitotenv.2020.140383

66. Zhao Z, Zhang L, Wu J (2016) Polycyclic aromatic hydrocarbons (PAHs) and organochlorine pesticides (OCPs) in sediments from lakes along the middle-lower reaches of the Yangtze River and the Huaihe River of China: The residues of PAHs and OCPs in freshwater lakes. Limnol. Oceanogr. 61, 47-60. https://doi.org/10.1002/Ino.10197

\section{Tables}

Table 1 Detection rate (DR), limit of detection (LOD), minimum (Min), maximum (Max), Median and Mean concentrations, coefficient of variance (CV) and relative abundances of 19 target OCPs in sediments form Ya-Er lake $(n=18)$ 


\begin{tabular}{|c|c|c|c|c|c|c|c|c|}
\hline & DR & LOD & Min & Max & Median & Mean & CV & Relative abundance \\
\hline & $\%$ & \multicolumn{5}{|c|}{$\mathrm{ng} \mathrm{g}^{-1} \mathrm{dw}$} & $\%$ & $\%$ \\
\hline $\mathrm{HCB}$ & 100.0 & 0.58 & 7.91 & 916.86 & 80.56 & 169.38 & 144.4 & $26.5-97.4$ \\
\hline $\mathrm{a}-\mathrm{HCH}$ & 100.0 & 0.07 & 0.11 & 29.56 & 1.77 & 4.93 & 157.1 & $0.1-16.2$ \\
\hline$\beta-\mathrm{HCH}$ & 100.0 & 0.00 & 1.56 & 17.87 & 4.52 & 5.77 & 71.4 & $0.2-25.8$ \\
\hline $\mathrm{Y}-\mathrm{HCH}$ & 94.4 & 0.17 & n.d. & 15.33 & 0.72 & 3.06 & 141.5 & $0.2-22.1$ \\
\hline$\delta-\mathrm{HCH}$ & 100.0 & 0.01 & 0.12 & 4.35 & 1.18 & 1.25 & 78.2 & $0.1-2.4$ \\
\hline$\Sigma \mathrm{HCHs}$ & & & 3.39 & 54.68 & 9.58 & 15.02 & 88.7 & $1.8-51.5$ \\
\hline$p, p^{\prime}-\mathrm{DDD}$ & 77.8 & 0.05 & n.d. & 4.38 & 0.41 & 0.76 & 142.2 & $0.1-6.6$ \\
\hline$p, p^{\prime}$ DDE & 100.0 & 0.00 & 0.39 & 10.11 & 1.72 & 1.99 & 110.9 & $0.1-5.5$ \\
\hline$o, p^{\prime}$-DDT & 72.2 & 0.11 & n.d. & 4.85 & 0.47 & 0.94 & 141.6 & $0.1-6.5$ \\
\hline$p, p^{\prime}-\mathrm{DDT}$ & 44.4 & 0.59 & n.d. & 5.33 & 0.00 & 1.10 & 141.8 & $0.1-2.9$ \\
\hline ¿DDTs & & & 0.39 & 17.13 & 4.01 & 4.80 & 99.0 & $0.4-15.5$ \\
\hline Methoxychlor & 100.0 & 0.03 & 0.04 & 8.16 & 0.74 & 1.79 & 125.1 & $0.0-19.3$ \\
\hline trans-Chlordane & 100.0 & 0.01 & 0.01 & 0.65 & 0.13 & 0.20 & 93.1 & $0.0-0.3$ \\
\hline cis-Chlordane & 100.0 & 0.00 & 0.05 & 2.68 & 0.45 & 0.79 & 93.6 & $0.0-4.2$ \\
\hline$\Sigma \mathrm{CDs}$ & & & 0.08 & 3.02 & 0.81 & 0.99 & 82.0 & $0.1-4.4$ \\
\hline Heptachlor & 94.4 & 0.01 & n.d. & 0.94 & 0.17 & 0.28 & 99.8 & $0.1-1.5$ \\
\hline Heptachlor-epoxide & 100.0 & 0.02 & 0.06 & 2.41 & 0.35 & 0.55 & 122.1 & $0.0-2.3$ \\
\hline$\Sigma \mathrm{HTs}$ & & & 0.21 & 3.07 & 0.53 & 0.82 & 100.4 & $0.0-3.7$ \\
\hline a-Endosulfan & 72.2 & 0.00 & n.d. & 0.25 & 0.02 & 0.07 & 122.7 & $0.0-0.2$ \\
\hline$\beta$-Endosulfan & 77.8 & 0.00 & n.d. & 0.66 & 0.04 & 0.15 & 132.0 & $0.0-1.4$ \\
\hline$\Sigma$ ESs & & & n.d. & 0.80 & 0.09 & 0.21 & 111.9 & $0.0-1.6$ \\
\hline Aldrin & 66.7 & 0.04 & n.d. & 0.75 & 0.09 & 0.17 & 128.0 & $0.1-0.8$ \\
\hline Dieldrin & 94.4 & 0.01 & n.d. & 0.34 & 0.05 & 0.08 & 116.6 & $0.0-0.4$ \\
\hline Endrin & 77.8 & 0.00 & n.d. & 0.17 & 0.05 & 0.05 & 97.6 & $0.0-0.2$ \\
\hline$\sum$ Drins & & & n.d. & 1.03 & 0.19 & 0.30 & 92.2 & $0.0-1.1$ \\
\hline$\Sigma O C P s$ & & & 29.82 & 941.79 & 99.89 & 193.32 & 127.5 & \\
\hline
\end{tabular}

"n.d." Not detected.

Table 2 Ecological risk assessment of OCPs in sediments from Ya-Er lake $(n=18)$ with the corresponding sediment quality guidelines 


\begin{tabular}{|c|c|c|c|c|c|c|c|c|c|c|}
\hline \multirow[t]{2}{*}{ Compounds } & \multirow[t]{2}{*}{$\begin{array}{l}\text { Concentration } \\
\text { range (ng g- } 1 \text { ) }\end{array}$} & \multicolumn{2}{|c|}{$\begin{array}{l}\text { Guideline } \\
\text { value (ng g-1) }\end{array}$} & \multicolumn{3}{|c|}{ Ratios (\%) } & \multicolumn{2}{|c|}{$\begin{array}{l}\text { Guideline } \\
\text { value (ng g- } \\
\text { 1) }\end{array}$} & \multicolumn{2}{|l|}{ Ratios (\%) } \\
\hline & & $\mathrm{ERL}^{\mathrm{a}}$ & ERM $^{\mathrm{a}}$ & $<E R L$ & ERL ERM & $>$ ERM & $\mathrm{TEL}^{\mathrm{b}}$ & $\mathrm{PEL}^{\mathrm{b}}$ & TEL PEL & $>$ PEL \\
\hline HCB & 7.91-916.86 & $20^{c}$ & $240^{c}$ & 6 & 78 & 17 & n.g. & n.g. & - & - \\
\hline $\mathrm{a}-\mathrm{HCH}$ & $0.11-29.56$ & 0.32 & 1 & 17 & 6 & 78 & 0.94 & 1.38 & 22 & 56 \\
\hline$\beta-\mathrm{HCH}$ & $1.56-17.87$ & 0.32 & 1 & 0 & 0 & 100 & 0.94 & 1.38 & 0 & 100 \\
\hline $\mathrm{Y}-\mathrm{HCH}$ & n.d.-15.33 & 0.32 & 1 & 28 & 39 & 33 & 0.94 & 1.38 & 0 & 33 \\
\hline$\delta-\mathrm{HCH}$ & $0.12-4.53$ & 0.32 & 1 & 17 & 28 & 56 & 0.94 & 1.38 & 39 & 33 \\
\hline$o, p^{\prime}-\mathrm{DDT}$ & n.d.-4.85 & 1 & 7 & 72 & 28 & 0 & 1.19 & 4.77 & 17 & 6 \\
\hline$p, p^{\prime}-\mathrm{DDT}$ & n.d.-5.33 & 1 & 7 & 56 & 44 & 0 & 1.19 & 4.77 & 39 & 6 \\
\hline$p, p^{\prime}-\mathrm{DDD}$ & n.d.-4.38 & 2 & 20 & 94 & 6 & 0 & 3.54 & 8.51 & 6 & 0 \\
\hline$p, p^{\prime}-\mathrm{DDE}$ & $0.39-10.11$ & 2.2 & 27 & 89 & 11 & 0 & 1.42 & 6.75 & 50 & 6 \\
\hline Heptachlor & n.d.-0.94 & 0.5 & 6 & 88 & 12 & 0 & 2.26 & 4.79 & 0 & 0 \\
\hline $\begin{array}{l}\text { Heptachlore- } \\
\text { poxide }\end{array}$ & $0.06-2.41$ & n.g. & n.g. & - & - & - & 0.6 & 2.74 & 22 & 0 \\
\hline$\Sigma$ Chlordane & $0.08-3.02$ & 0.5 & 6 & 39 & 61 & 0 & 4.5 & 8.87 & 0 & 0 \\
\hline Dieldrin & n.d.-0.34 & 0.02 & 8 & 22 & 78 & 0 & 2.85 & 6.67 & 0 & 0 \\
\hline Endrin & n.d.-0.17 & 0.02 & 45 & 33 & 67 & 0 & 2.67 & 62.4 & 0 & 0 \\
\hline
\end{tabular}

"n.g." No guideline. "-" No available data.

${ }^{a} E R L$ effect range-low value, ERM effect range-medium value (Long et al., 1995).

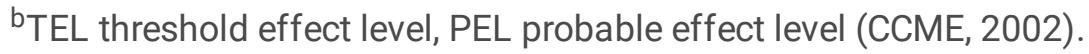

'LEL lowest effect level (OMOE, 1993)

Table 3 Rotated component matrix of OCPs from Ya-Er lake 


\begin{tabular}{|c|c|c|c|c|c|}
\hline \multirow[t]{2}{*}{ OCPs } & \multicolumn{5}{|l|}{ Principal components } \\
\hline & 1 & 2 & 3 & 4 & 5 \\
\hline $\mathrm{a}-\mathrm{HCH}$ & 0.913 & -0.043 & 0.298 & -0.033 & -0.111 \\
\hline$p, p^{\prime}-\mathrm{DDE}$ & 0.912 & 0.049 & 0.041 & -0.138 & -0.016 \\
\hline$\delta-\mathrm{HCH}$ & 0.910 & -0.130 & -0.076 & 0.048 & 0.053 \\
\hline$p, p^{\prime}$-DDT & 0.902 & 0.082 & 0.294 & 0.021 & 0.027 \\
\hline trans-Chlordane & 0.724 & -0.021 & 0.155 & 0.542 & 0.211 \\
\hline$\gamma-\mathrm{HCH}$ & 0.600 & -0.258 & -0.036 & -0.078 & -0.477 \\
\hline $\begin{array}{l}\text { Heptachlor- } \\
\text { epoxide }\end{array}$ & -0.127 & 0.818 & -0.069 & -0.193 & -0.082 \\
\hline Aldrin & -0.070 & 0.800 & 0.116 & -0.023 & 0.351 \\
\hline Methoxychlor & 0.028 & 0.787 & 0.256 & -0.047 & 0.103 \\
\hline Heptachlor & -0.081 & 0.728 & 0.197 & 0.200 & -0.196 \\
\hline$\beta$-Endosulfane & 0.121 & 0.704 & 0.073 & -0.069 & 0.564 \\
\hline$p, p^{\prime}$-DDD & 0.074 & -0.042 & 0.947 & 0.067 & -0.163 \\
\hline$o, p^{\prime}$-DDT & 0.113 & 0.307 & 0.891 & 0.039 & 0.118 \\
\hline cis-Chlordane & 0.171 & 0.064 & 0.781 & 0.106 & 0.288 \\
\hline a-Endosulfan & 0.201 & 0.514 & 0.676 & 0.016 & 0.057 \\
\hline HCB & 0.209 & -0.172 & 0.019 & 0.811 & -0.221 \\
\hline$\beta-\mathrm{HCH}$ & 0.282 & 0.149 & -0.299 & -0.702 & -0.208 \\
\hline Endrin & -0.111 & 0.520 & -0.088 & 0.693 & -0.086 \\
\hline Deildrin & -0.016 & 0.013 & 0.111 & -0.065 & 0.923 \\
\hline $\begin{array}{l}\text { Estimated } \\
\text { source }\end{array}$ & $\begin{array}{l}\text { Historical industrial } \\
\text { input }\end{array}$ & $\begin{array}{l}\text { Recent agricultural } \\
\text { input }\end{array}$ & $\begin{array}{l}\text { Historical mixture } \\
\text { input }\end{array}$ & $\begin{array}{l}\text { Persistent } \\
\text { residuals }\end{array}$ & Diedrin \\
\hline Variance (\%) & 27.6 & 23.4 & 12.3 & 9.5 & 8.2 \\
\hline
\end{tabular}

Table 4 Simple and conditional effects obtained from the summary of forward selection for the nine dominant OCP variables. 


\begin{tabular}{|c|c|c|c|c|c|c|c|}
\hline \multirow[t]{2}{*}{ Variables } & \multicolumn{3}{|c|}{ Simple effect } & \multirow[t]{2}{*}{ Variables } & \multicolumn{3}{|c|}{ Conditional effect } \\
\hline & Explains \% & pseudo-F & $\mathrm{P}$ & & Explains \% & pseudo-F & $\mathrm{P}$ \\
\hline$p, p^{\prime}-\mathrm{DDT}$ & 39.1 & 10.3 & 0.004 & $p, p$-DDT & 39.1 & 10.3 & 0.002 \\
\hline $\mathrm{a}-\mathrm{HCH}$ & 36.2 & 9.1 & 0.002 & НСВ & 15.1 & 4.9 & 0.022 \\
\hline$\delta-\mathrm{HCH}$ & 34.5 & 8.4 & 0.002 & $o, p^{\prime}=\mathrm{DDT}$ & 8.8 & 3.3 & 0.010 \\
\hline$p, p^{\prime}-\mathrm{DDE}$ & 24.5 & 5.2 & 0.024 & $\delta-\mathrm{HCH}$ & 5.3 & 2.2 & 0.068 \\
\hline HCB & 23.2 & 4.8 & 0.030 & $\mathrm{a}-\mathrm{HCH}$ & 3.9 & 1.7 & 0.158 \\
\hline $\mathrm{Y}-\mathrm{HCH}$ & 16.0 & 3.1 & 0.046 & $p, p^{\prime}-\mathrm{DDD}$ & 1.7 & 0.7 & 0.556 \\
\hline$p, p^{\prime}-\mathrm{DDD}$ & 12.9 & 2.4 & 0.114 & $p, p^{\prime} \mathrm{DDE}$ & 1.2 & 0.5 & 0.796 \\
\hline$o, p^{\prime}-\mathrm{DDT}$ & 12.6 & 2.3 & 0.094 & $\beta-\mathrm{HCH}$ & 2.2 & 0.9 & 0.448 \\
\hline$\beta-\mathrm{HCH}$ & 2.1 & 0.3 & 0.826 & $\gamma-\mathrm{HCH}$ & 1.1 & 0.4 & 0.778 \\
\hline
\end{tabular}

Table 5 Concentrations of HCB, HCHs and DDTs in sediments in Ya-Er lake area and other lakes (ng g ${ }^{-1}$ ) 


\begin{tabular}{|c|c|c|c|c|c|c|}
\hline \multirow[t]{2}{*}{ Location } & \multirow{2}{*}{$\begin{array}{l}\text { Sampling } \\
\text { time }\end{array}$} & \multirow{2}{*}{$\begin{array}{l}\text { Depth } \\
\text { (cm) }\end{array}$} & $\mathrm{HCB}$ & $\Sigma \mathrm{HCHs}$ & $\Sigma \mathrm{DDTs}$ & \multirow[t]{2}{*}{ Reference } \\
\hline & & & \multicolumn{3}{|c|}{ Range (mean) /ng g ${ }^{-1} \mathrm{dw}$} & \\
\hline \multicolumn{7}{|c|}{ Ya-Er lake before dredging } \\
\hline Pond No.1-3 & \multirow[t]{2}{*}{1991} & \multirow[t]{2}{*}{$0-12$} & n.a. & $60.1,36.5,30.3$ & n.a. & \multirow[t]{2}{*}{ Xu et al. 1994;1999 } \\
\hline Pond No. 4-5 & & & n.a. & $18.9,12.8$ & n.a. & \\
\hline Pond No.1-5 & $\begin{array}{l}1991- \\
1994\end{array}$ & $20-40$ & $\begin{array}{l}31500- \\
57100\end{array}$ & $3.82-21.2$ & n.a. & Wu et al. 1997 \\
\hline \multicolumn{7}{|c|}{ Ya-Er lake after dredging } \\
\hline Pond No.1-3 & \multirow[t]{2}{*}{2009} & \multirow[t]{2}{*}{$0-12$} & $\begin{array}{l}0.13- \\
8.30 \\
(3.3)\end{array}$ & $\begin{array}{l}0.73-4.70 \\
(2.2)\end{array}$ & $\begin{array}{l}2.26- \\
8.67 \\
(5.6)^{a}\end{array}$ & \multirow[t]{2}{*}{ Liu et al. 2011} \\
\hline Pond No.4-5 & & & $\begin{array}{l}0.34- \\
8.80 \\
(2.5)\end{array}$ & $\begin{array}{l}2.16-19.88 \\
(8.5)\end{array}$ & $\begin{array}{l}2.85- \\
34.5 \\
(12.5)^{a}\end{array}$ & \\
\hline Surrounding Soils & 2015 & $0-20$ & n.a. & $\begin{array}{l}0.07-6.60 \\
(1.9)\end{array}$ & $\begin{array}{l}0.61- \\
111.2 \\
(21.2)^{b}\end{array}$ & Liu et al. 2017 \\
\hline $\begin{array}{l}\text { Pond No.1 } \\
\text { Lakebed }\end{array}$ & \multirow[t]{2}{*}{2018} & $10-40$ & $\begin{array}{l}32.18- \\
131 \\
(76.6)\end{array}$ & $\begin{array}{l}3.39-35.7 \\
(9.9)\end{array}$ & $\begin{array}{l}0.39- \\
7.04 \\
(2.2)^{a}\end{array}$ & \multirow[t]{2}{*}{ This study } \\
\hline $\begin{array}{l}\text { Pond No.1 } \\
\text { Lakeshore }\end{array}$ & & $50-270$ & $\begin{array}{l}7.91-917 \\
(285)\end{array}$ & $\begin{array}{l}8.30-54.7 \\
(21.4)\end{array}$ & $\begin{array}{l}3.93- \\
17.1 \\
(8.1)^{a}\end{array}$ & \\
\hline 92 lakes, China & $\begin{array}{l}2008- \\
2009\end{array}$ & $0-5$ & n.a. & $\begin{array}{l}\text { n.d.-113.0 } \\
(14.6)\end{array}$ & $\begin{array}{l}0.4- \\
66.0 \\
(10.7)^{c}\end{array}$ & Zhao et al. 2016 \\
\hline Poyang lake & 2011 & $0-5$ & $0.3-2.2$ & $\begin{array}{l}0.5-6.9 \\
(3.0)\end{array}$ & $\begin{array}{l}14.4- \\
82.9 \\
(46.7)^{b}\end{array}$ & Lu et al. 2012 \\
\hline Chaohu lake & 2011 & $0-5$ & n.a. & $0.04-7.12$ & $\begin{array}{l}0.23- \\
85.83\end{array}$ & Li et al. 2015 \\
\hline East Dongting lake & 2014 & $0-10$ & n.a. & $\begin{array}{l}2.1-6.4 \\
(3.2)\end{array}$ & $\begin{array}{l}0.5-3.0 \\
(1.3)^{c}\end{array}$ & Wei et al. 2019 \\
\hline Honghu lake & 2014 & $0-10$ & n.a. & $\begin{array}{l}1.0-2.6 \\
(1.3)\end{array}$ & $\begin{array}{l}0.1-2.1 \\
(0.5)^{c}\end{array}$ & \\
\hline Taihu lake basin & 2015 & $0-5$ & n.a. & $\begin{array}{l}3.3-64.5 \\
(13.0)\end{array}$ & $\begin{array}{l}0.2- \\
55.9\end{array}$ & Zhao et al. 2017 \\
\hline
\end{tabular}


$(8.8)^{\mathrm{c}}$

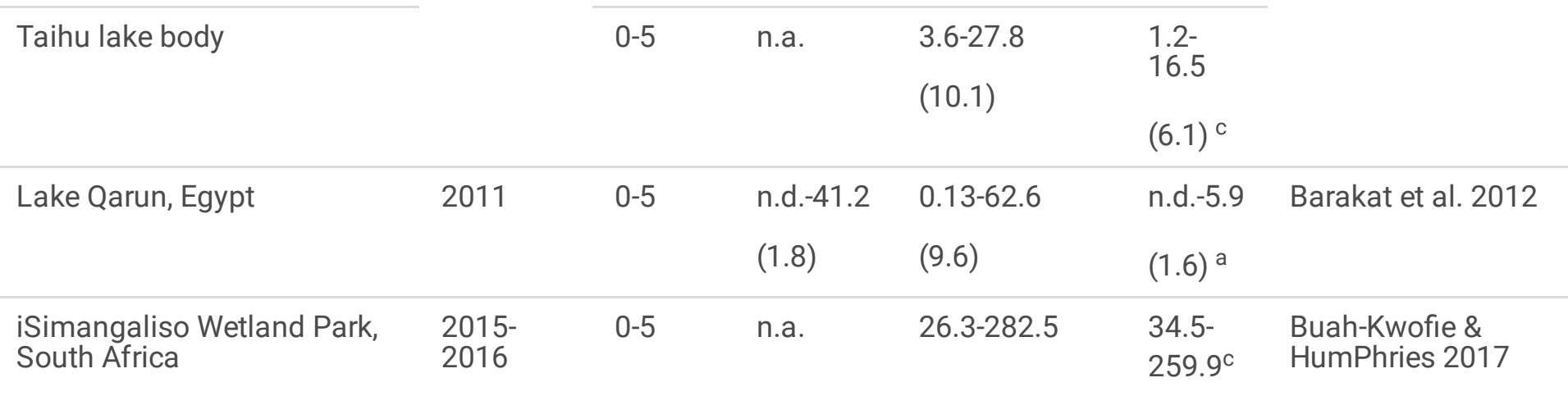

“n.a." Not available. "n.d." Not detected.

a $\Sigma \mathrm{DDT}=p, p^{\prime} \mathrm{DDD}+p, p^{\prime}-\mathrm{DDE}+o, p^{\prime}-\mathrm{DDT}+p, p^{\prime}-\mathrm{DDT}$

${ }^{\mathrm{b}} p, p^{\prime} \mathrm{DDD}+p, p^{\prime}-\mathrm{DDE}+o, p^{\prime}-\mathrm{DDD}+o, p^{\prime}-\mathrm{DDE}+o, p^{\prime}-\mathrm{DDT}+p, p^{\prime}-\mathrm{DDT}$

${ }^{c} p, p^{\prime}-\mathrm{DDD}+p, p^{\prime}-\mathrm{DDE}+p, p^{\prime}-\mathrm{DDT}$

\section{Figures}

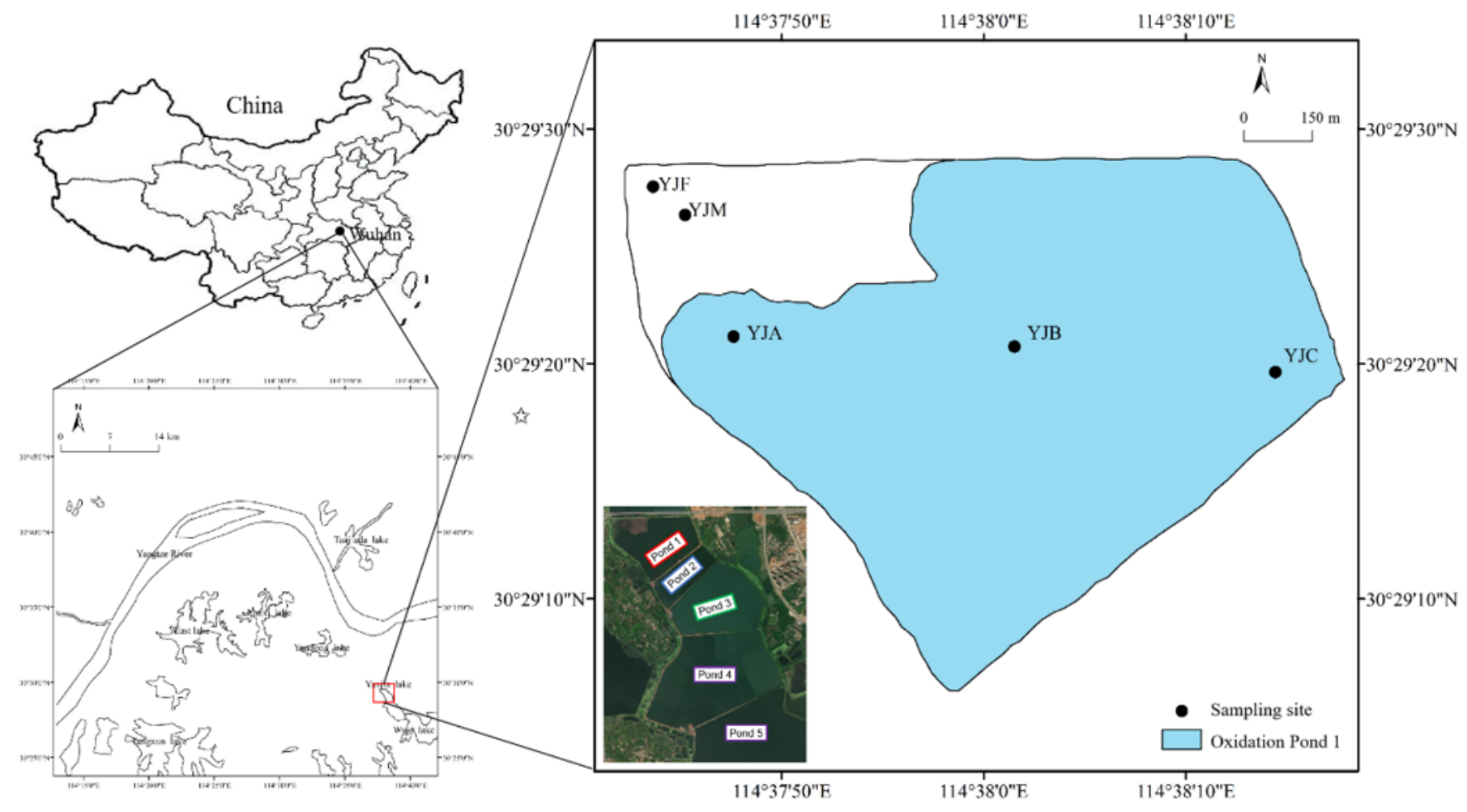

Figure 1

Location of the Ya-Er lake and the sampling sites at Pond No.1 Note: The designations employed and the presentation of the material on this map do not imply the expression of any opinion whatsoever on the part of Research Square concerning the legal status of any country, territory, city or area or of its authorities, or concerning the delimitation of its frontiers or boundaries. This map has been provided by the authors. 

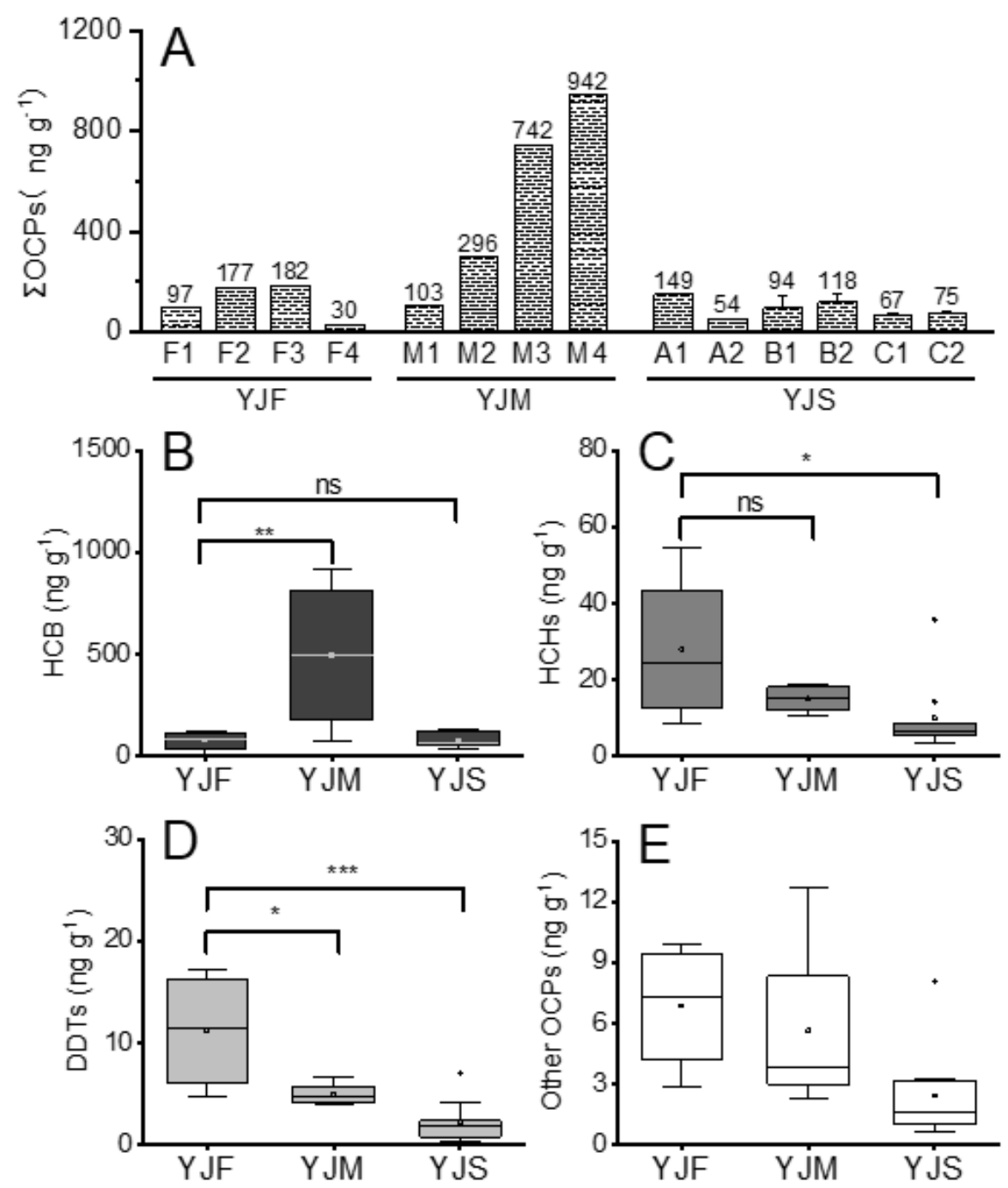

Figure 2

Concentrations of EOCPs (A), HCB (B), HCHs (C), DDTs (D) and the other OCPs (E) in the sediment core samples of Ya-Er Lake (YJF, YJM and YJS ( $A$ to $C$ ) from the inlet to outlet of the past wastewater flow in Pond No.1; the numbers after lakeshore sites F\&M indicate four layers: 1. 0.5-0.9 m; 2.0.9-1.5 m; 3. 1.5-2.0 m; 4. 2.0-2.7 m, while the numbers after lakebed sites A\&B\&C indicate two layers: $1.10-20 \mathrm{~cm} ; 2.30-40 \mathrm{~cm}$ ) 

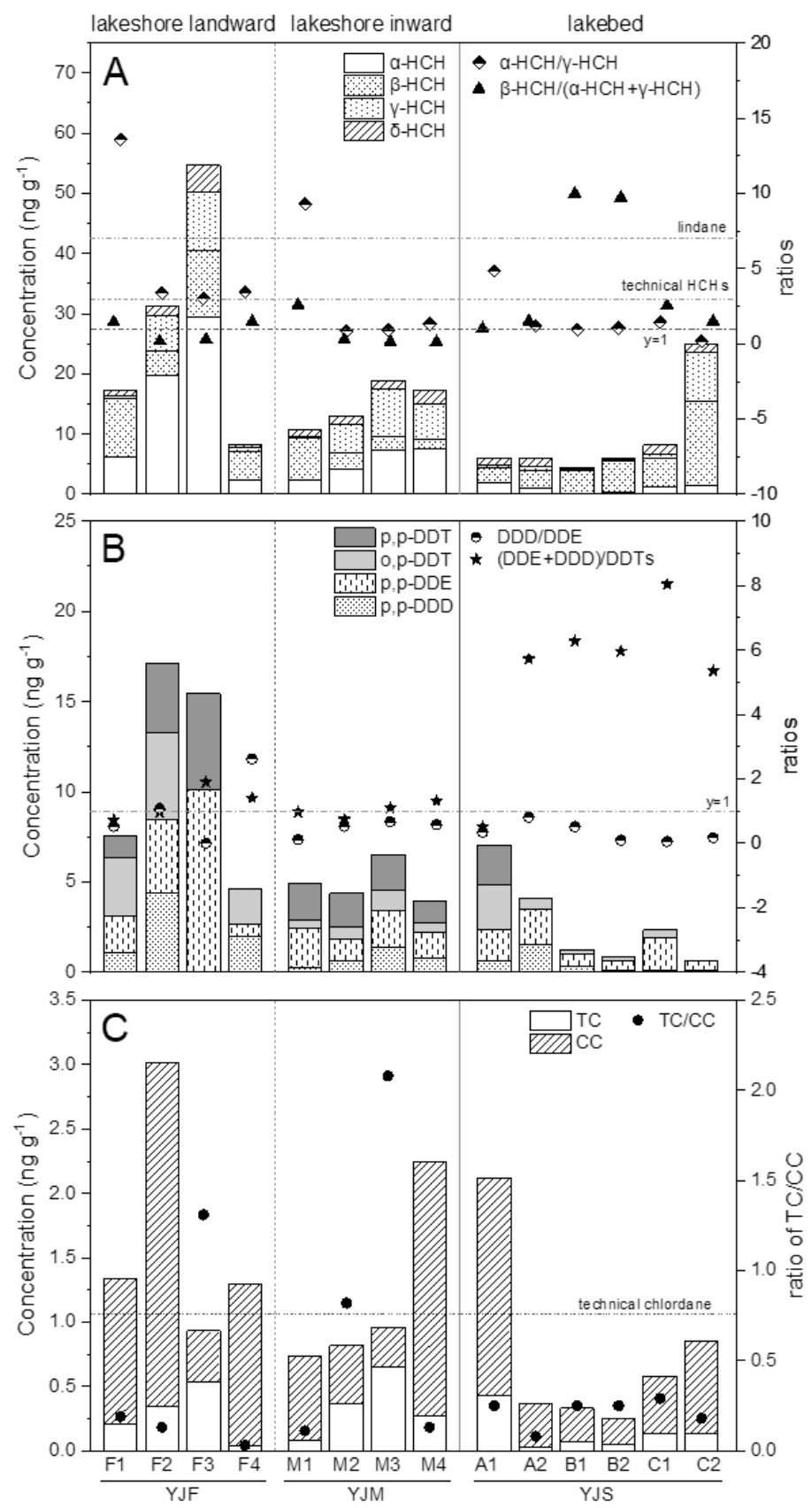

\section{Figure 3}

Composition and concentration distribution of $\mathrm{HCHs}(\mathrm{A})$, DDTs (B) and Chlordane (C) in the sediment core samples of Ya-Er lake. 

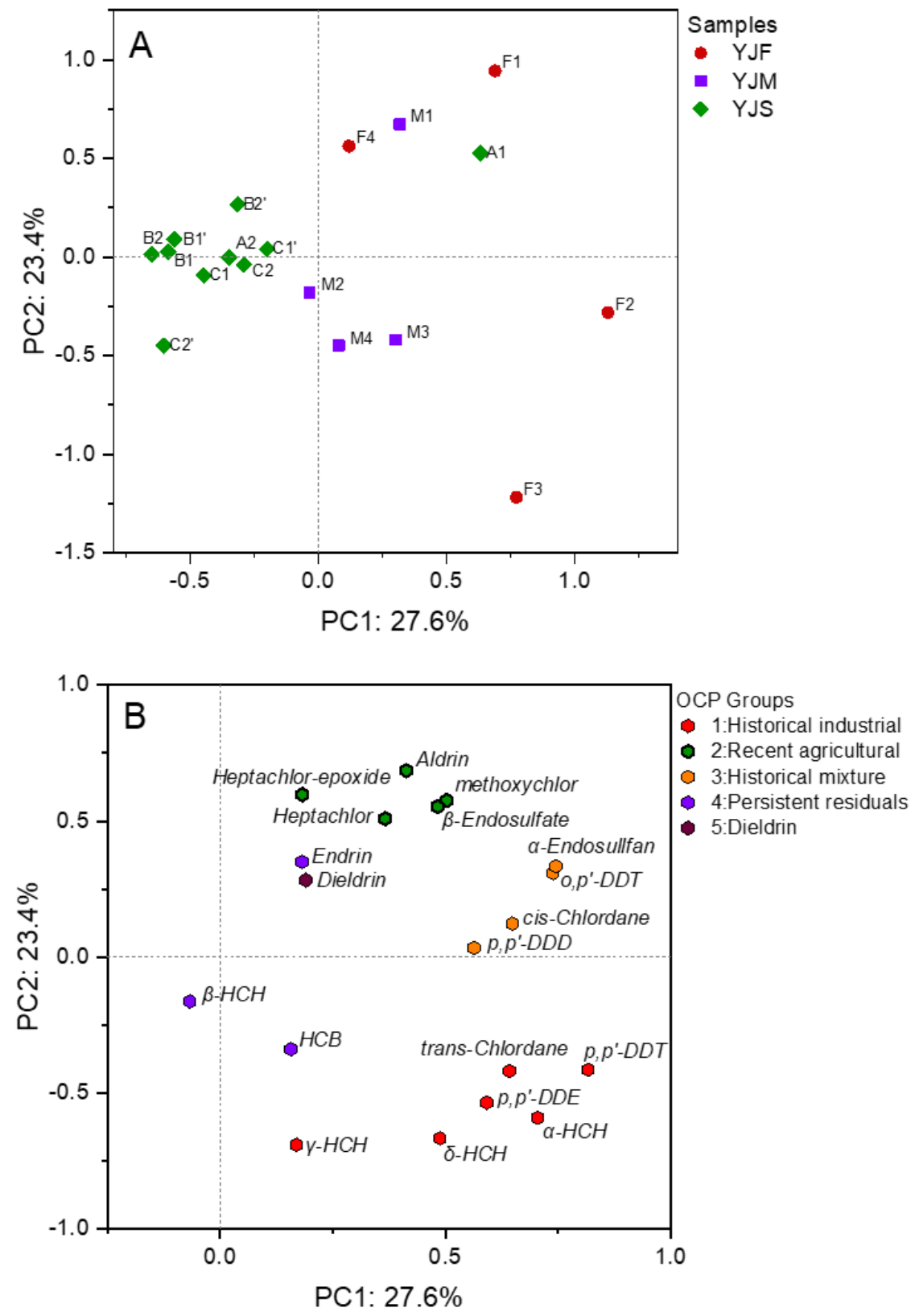

\section{Figure 4}

Sample score plot (A) and loading plot of OCPs (B) based on the PCA analysis of OCP profiles in sediment core samples from Ya-Er lake. OCP groups are obtained according to the rotated component matrix, showing significant OCPs to each PCs (|loadings|>0.6) 

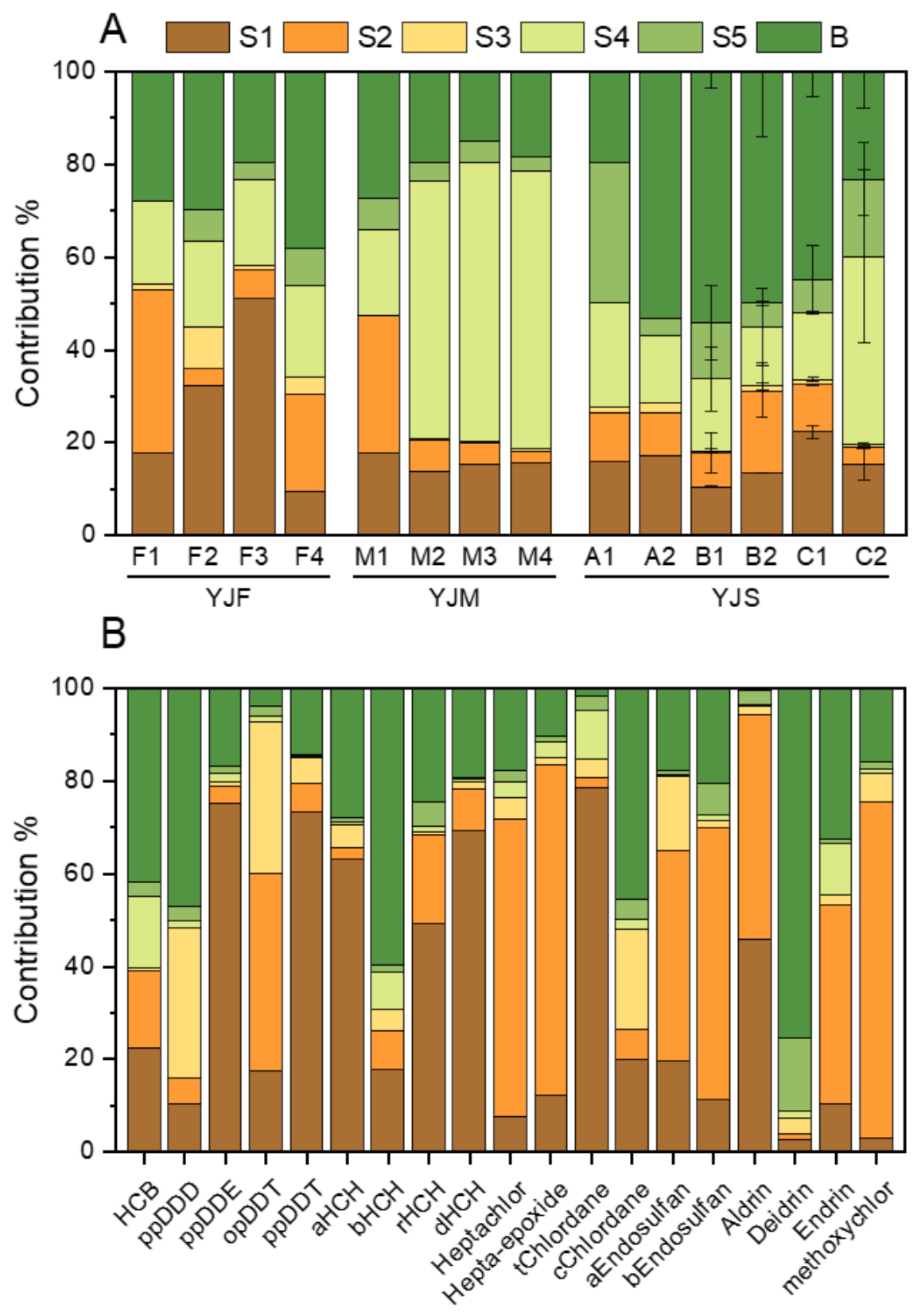

Figure 5

Source contributions of OCPs to each site (A) and to each OCP variable (B) by APCS-MLR model in subsurface sediments of Ya-Er lake. S1 indicates historical industrial input; S2 indicates recent agricultural input; S3 indicates historical mixture input; S4 indicates persistent residuals of $\mathrm{HCB}$ and $\beta-\mathrm{HCH}$; S5 is Diedrin; B indicates unidentified source. 

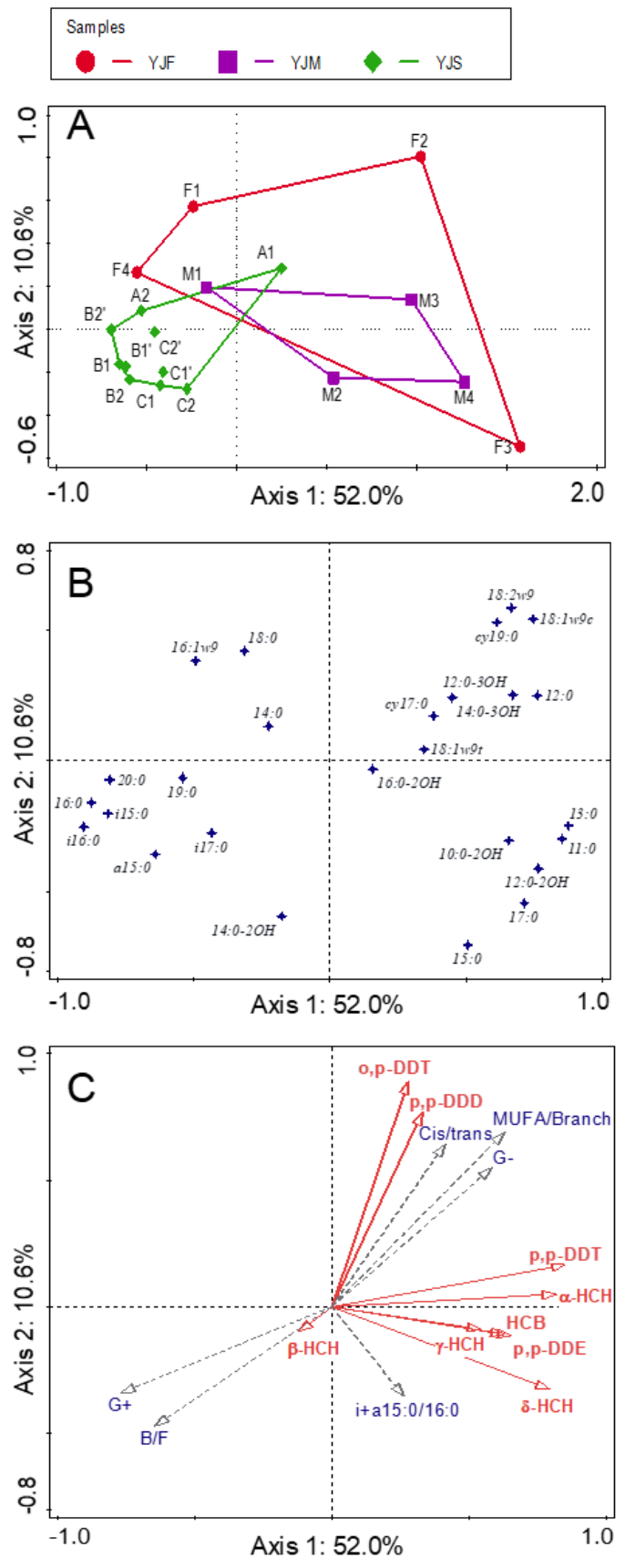

\section{Figure 6}

Sample score plot (A), loading plot of fatty acids (B) and biplot of OCPs-FAME biomarkers (C) based on the RDA analysis of EL-FAMEs profiles and the nine dominant OCPs in sediment core samples from Ya-Er lake. The six FAME biomarkers (G+: gram-positive bacteria; G-: gram-negative bacteria; MUFA/Branch: monounsaturated fatty acids/branched fatty

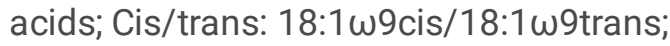

